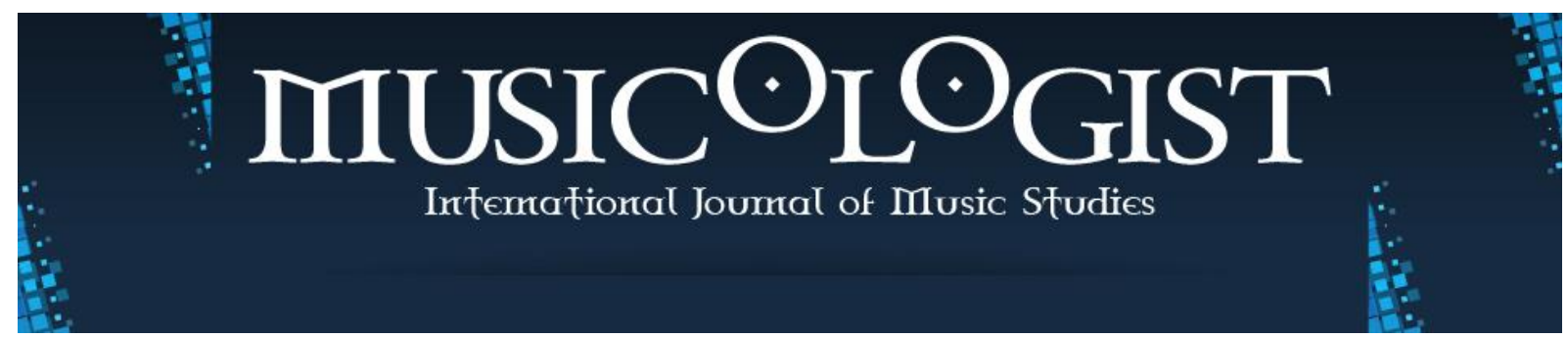

Trabzon University State Conservatory @ $2017-2020$

Volume 4 Issue 1 June 2020

Research Article

Musicologist 2020. 4 (1): 101-137

DOI: $10.33906 /$ musicologist.703903

\author{
ERIN KIRK \\ California Baptist University, USA \\ ekirk@calbaptist.edu \\ orcid.org/0000-0001-6765-0241
}

\title{
The Development of an American Sound: From the Perspective of Twentieth Century Masters, Aaron Copland \& Leonard Bernstein
}

\begin{abstract}
As musicologists and scholars of American art music, we are forever indebted to Aaron Copland and Leonard Bernstein for their music, their conducting, teaching, and lecturing, and especially for their writings. It is still a relatively recent phenomenon in the history of music to possess writings from composers that explain, not only their own works, but their perspective on all aspects of the musical world in which they lived. One significant topic which both Copland and Bernstein addressed was the process by which a uniquely American sound began to develop and shape the music of the twentieth century.

Through a thorough examination of their writings, supporting research from other scholars, and original analysis of key musical works, this article will trace the beginnings of a nationalistic thread in American art music and identify the musical traits that communicate such nationalism. Both Copland and Bernstein identified influential figures in the development of an American sound, such as Antonin Dvorák, Nadia Boulanger, Charles Ives, George Gershwin, Aaron Copland, Virgil Thomson, William Schuman, Roy Harris, and Carlos Chávez. Also, jazz, folk music, and Latin American music were highly influential to the art music of the twentieth century.

Looking back throughout history, there is rarely one defining moment when music changes completely. It is usually a combination of many and varied factors that occur throughout a period of time. In this study, identifying the causes and influences in the development of an American nationalistic sound, we have the distinct benefit of taking cues from some of the most influential figures in twentieth century art music who blessed musicians, music-lovers, and scholars with their words, eloquently bringing to light the serendipitous events that created the art music of the last century.
\end{abstract}

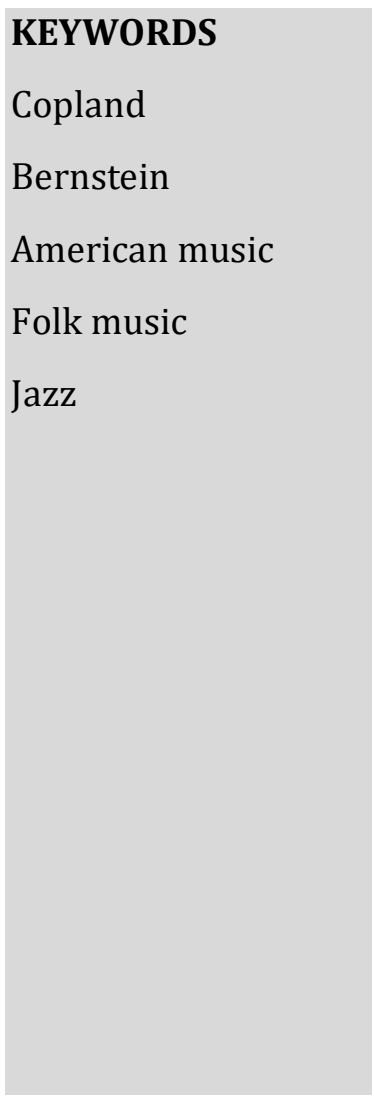


In the twentieth century, a nationalistic American sound began to develop in the world of art music; a music full of buoyancy, bounce, and exuberance; of 'pioneering' experimentation; of jazz inspiration; an expression of big industrial cities and wide-open prairies, of "America's physical, geographical vastness" (Mellers, 1948: 19). Composer, author, critic, conductor, lecturer, and 'Dean of American Composers,' Aaron Copland, greatly contributed to this sound in his own compositions, but also in his writings and lectures. Both Aaron Copland and Leonard Bernstein were extremely influential figures in the world of twentieth century art music, and arguably remain so today.

In this article, we will investigate American nationalistic art music from the perspective of these two influential figures. Through a thorough examination of their words, we will search for the beginnings of a nationalistic thread in American art music and identify the musical traits that communicate such nationalism. To trace the development of an American sound in music, we must first look at some of its precursors, both American and European, which sparked a change in the historical and cultural context of this music.

\section{Antonin Dvorák (1887-1979)}

Dvorák, a leading composer in the Czech national movement, was well-known as a nationalistic composer. On a two-year visit to America in 1892 (Copland, 1952: 103; Bernstein, 1962a: 150), Dvorák was shocked to find that American composers were not composing music in a nationalistic style, as he was accustomed. To these American composers, he said, "Look at your country. Here you live in a land abounding in folk traditions and folk material of the most varied and exotic kinds. What of your Indians, with their noble chants and dances? What of your [African-Americans], with their spirituals, ballads, laments, and work songs? Why do you not create a wealth of symphonic music from this treasury of material? You have a heritage; all you have to do is use it" (Dvorák, paraphrased in Bernstein, 1962a: 150). The inherent fault with this logic is that these particular American composers were not of Native American or African-American heritage and had no connection to the native music of which he spoke (Bernstein, 1962b: 38-39). Dvorák committed to writing an American-sounding symphony to show American composers his method for composing nationalistic music. The result was his Symphony No. 9, 'From the New World', which is commonly nicknamed, the New World Symphony. In his endeavor for an American sound, he 
incorporated Native American themes and some African-American themes because he felt that this was the indigenous folk music of America (Bernstein, 1962b: 39).

One of the best-known themes from the second movement of the New World Symphony is called “Goin' Home" (Bernstein, 1962b: 39), and though it possesses the qualities of a preexistent spiritual, Dvorák created the melody specifically for this piece. Depending on the setting and treatment, however, this melody could be extremely versatile. In Bernstein's estimation, the same melody set with Czech words or Czech accompaniment would sound Czech. Its dotted-rhythms and simple, conjunct motion classify the melody as folk-like (see example below), but not necessarily American.

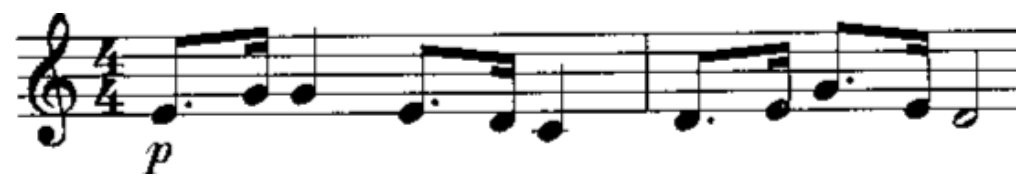

Figure 1: “Goin' Home” (Bernstein, 1962b: 38-39).

At Dvorák's suggestion, many composers began writing what they thought were "American-sounding" pieces utilizing Native American and African-American melodies (Bernstein, 1962b: 40). Unfortunately, since none of these composers had any connection with the heritage of this native music, the lifespan of the music was greatly limited. According to Copland, "You can't just decide to be American; you can't just sit down and say, 'I'm going to write American music, if it kills me'; you can't be nationalistic on purpose" (Bernstein, 1962b: 40).

In Copland's expert opinion, "there is nothing inherently pure in a melody of folk source that cannot be effectively spoiled by a poor setting" (Copland, 1952: 103). Thus, the usefulness of incorporating folk material into one's composition is negated when a composer is unable to identify with the source and "re-express in his own terms, the underlying emotional connotation of the material" (Copland, 1952: 104). Reflection of emotion, an appropriate setting, and an imaginative and unconventional approach, rather than mere quotation, are essential in producing effective folk-influenced music (Copland, 1952: 104). This was a fundamental problem with Dvorák's New World Symphony and with the many American composers whom he influenced. They were all able to use folk material in their compositions, but the harmonic language and treatment of the themes did not match the origin of the folk themes. In Dvorák's case, the music 
sounded Czech, or at least European, as do many of his other compositions, because his particular style and tonal language remained consistent, in spite of his attempt to compose an American sounding piece. The other American composers who attempted nationalistic music under his influence had a similar conundrum. Their music, other than the folk material they borrowed, sounded European because they studied composition in Europe and that was the musical language with which they were familiar (Bernstein, 1962a: 150).

Dvorák made a significant impression on the composers with whom he came in contact during his stay in America. And although the seemingly simple formula for writing nationalistic art music was not a complete success for these composers, it began the process that would eventually revolutionize the world of American music. In short, he identified the 'problem', which Copland, Bernstein, and numerous other composers strove to remedy in the twentieth century.

\section{Nadia Boulanger (1887-1979)}

As with Dvorák, it may seem strange to include a non-American in a discussion about influencers of American art music, but Nadia Boulanger is credited as being one of the most influential people for Aaron Copland and numerous other composers in the twentieth century.

In 1921, a summer music school was established at the Palace of Fontainebleau, in which Nadia Boulanger was an instructor of harmony (Copland, 1960: 83). She was known for her wonderfully warm personality and her ability to teach with verve. An introduction was made by one of Copland's colleagues and he quickly developed a great deal of admiration and respect for Ms. Boulanger. It was not until Copland auditioned to become her pupil that she began teaching advanced composition on an individual basis (Copland, 1960: 84).

She knew everything about music from all eras, including technical information on harmonic transposition, figured bass, score reading, organ registration, instrumental techniques, structural analyses, all types of fugues, modes, and Gregorian chant (Copland, 1960: 87). "She had the teacher's consuming need to know how all music functions, and it was that kind of inquiring attitude that registered on the minds of her students" (Copland, 1960: 88). She also had a unique ability to bestow on her students a 
sense of confidence that they were able to achieve beyond their perceived abilities. Her intuition and forethought as a musician gave her the ability to see potential, as well as flaws, in unfinished works. She was especially concerned with "la grande ligne"--the musical line, "the sense of forward motion, of flow and continuity in the musical discourse; the feeling for inevitability, for the creating of an entire piece that could be thought of as a functioning entity" (Copland, 1960: 90). She was also concerned with the bassline, the structural framework of the piece, the progression of harmony, a keen sense of contrast and balance, and "clarity of conception and elegance in proportion" (Copland, 1960: 90).

"It was her broadness of sympathy that made it possible for her to apply these general principles to the music of young men and women of so many different nationalities" (Copland, 1960: 90). And it is for this reason that she mentored so many American composers, helping them to grow in their compositional technique and maturity, and, most importantly, helping them find their own voice. This mentorship produced generations of composers that did not return home copying the style of European music, but were able to create, for the first time, truly unique and American art music. The list of Nadia Boulanger's American pupils is quite extensive and includes Aaron Copland, Walter Piston, Virgil Thomson, Roy Harris, Marc Blitzstein, Elliott Carter, David Diamond, Irving Fine, Harold Shapero, and Arthur Berger, to name a few (Copland, 1960: 91). Nadia Boulanger, though French by nationality, accomplished an incredible amount for the cause of American nationalistic music.

From Copland's viewpoint, the teachings of Ms. Boulanger were invaluable, as evidenced by his own words in a letter on November 24, 1950: "It's almost 30 years since we met.. . and I still count our meeting the most important event in my musical life" (Crist, 2006: 203). For Copland, his inspiration from the great teacher was not restricted to his period of study in Paris. They continued to correspond through letters and occasional meetings in Paris and in America throughout the remainder of her life. Copland also sought her input on his pieces, sending scores of his works both before and after publication for her review. 


\section{Charles Ives (1874-1954)}

According to Leonard Bernstein, Ives was "perhaps the first great composer in American history" (Bernstein, 1962b: 175). His "serious musical style" (Copland, 2004: 155) attempted to blend war songs and street songs for a truly unique sound. His approach involved quotation of popular songs in their 'unadulterated' form while the remainder of the music employed some rather complex harmonies. The effect resembled a patchwork quilt rather than a cohesive piece of music. Consequently, these were some of his least successful pieces.

Ives was "deeply immersed in his American roots... the village church choir, the Fourth of July celebration, the firemen's band, a barn dance, a village election, George Washington's Birthday" (Copland, 1952: 103). He treated these subjects more imaginatively than literally. "What is most impressive [about Ives] is not his evocation of a local landscape but the over-all range and comprehensiveness of his musical mind" (Copland, 1952: 103).

In contrast to his war songs and street songs, Ives' second symphony was a more cohesive example of a blending of folk and "serious" styles. Ives deliberately quotes folk tunes in this symphony, but he also "imitates the spirit of American folk music in general" (Bernstein, 1962b: 174). Ives was greatly influenced by folk material, such as hymns, patriotic songs, popular country music, and Stephen Foster melodies. Sometimes, he quoted directly from these sources, while in other compositions he chose not to utilize direct quotation. In the final movement of his second symphony, for example, there are tunes that resemble barn dances or Foster melodies, but instead are Ives' way of assimilating different folk materials into his own personal style. In this movement, Ives quoted at least 5 well-known folk tunes (Bernstein, 1962b: 176).

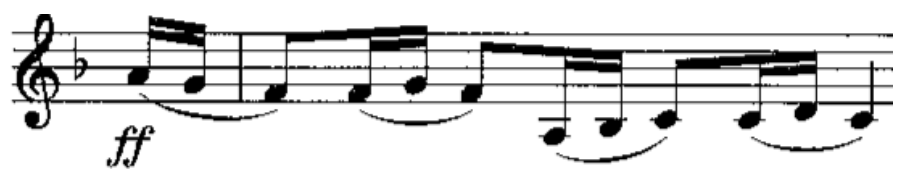

Figure 2: "Turkey in the Straw" (Bernstein, 1962b: 174-76). 


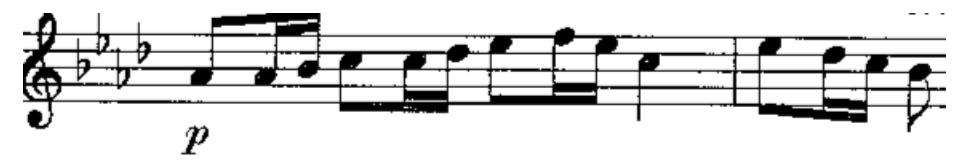

Figure 3: “Long, Long Ago” (Bernstein, 1962b: 174-76).

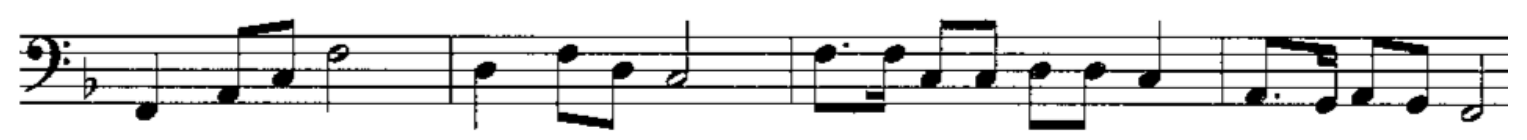

Figure 4: “Camptown Races” (Bernstein, 1962b: 174-176).

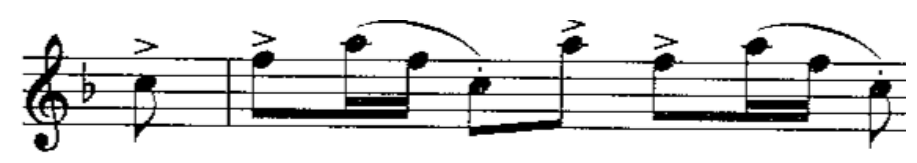

Figure 5: "Reveille” (Bernstein, 1962b: 174-176).

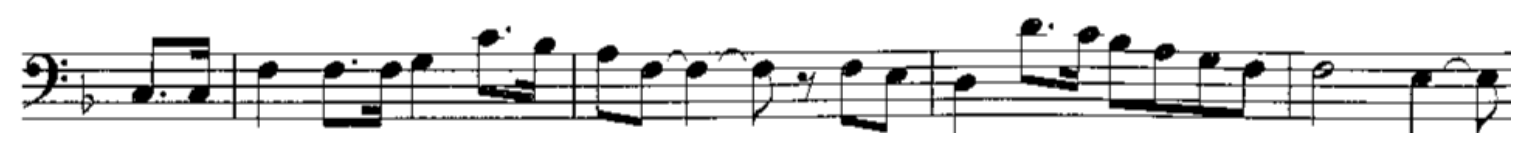

Figure 6: “Columbia the Gem of the Ocean” (Bernstein, 1962b: 174-176).

Because of his adoption of folk tunes, Ives is able to reflect a portion of America's historical sound and spirit in this symphony (Bernstein, 1962b: 175). Copland also quoted "Camptown Races" in Lincoln Portrait as a way of capturing the time period in which the former president lived, possibly influenced by Ives in this regard. Using folk material has a two-pronged effect. First, it helps listeners identify with the nationality of origin of the folk music. It also identifies with the time period in which the melody was written and/or when it was best-known. This is perhaps why Ives and Copland were so effective in their use of folk elements. Both composers chose specific tunes to help portray their desired mood or affect. Used in isolation from an effective setting, as Bernstein pointed out, these folk elements would have been less effective, but assimilated into one's compositional style, these folk songs can help create a very successful piece. 
One of Ives' great innovations was called 'musical perspective,' which imitated his experience as a child listening to three street bands playing simultaneously in different places. An example of this device can be seen in his 1907 piece, Central Park in the Dark. The piece involves two different performing groups: a muted string orchestra behind a curtain and a woodwind ensemble in front of the curtain. The strings were meant to portray the sounds of the night, while the woodwinds imitated city noises. "The music seems to exist independently on different planes" (Copland, 1952: 106).

This technique of 'musical perspective was well ahead of its time. These types of spatial effects would later influence American composers as well as composers throughout the world. Likewise, Ives made significant progress in the incorporation of popular or folk elements in 'serious' art music.

\section{The Influence of Jazz}

Both Copland and Bernstein agreed that jazz elements influenced many composers throughout the world. However, in this article, we will specifically investigate the influence of jazz on American art music composers. Copland's 1927 article on Jazz Structure and Influence (Copland, 2004: 83), dealt with both the origins of jazz and its specific characteristics (rhythm, timbre, structure).

Among the many diverse elements of jazz, the most foundational is rhythm (Copland, 2004: 83). "Jazz is a certain way of sounding two rhythms at once... a counterpoint of regular against irregular beats" (Virgil Thomson quoted in Copland, 2004: 83). First, Copland traces the origin of jazz rhythm to spirituals and then ragtime, with its characteristic unchanging bassline made up of four equal quarter notes per bar. Over the bassline lies a couple of rhythmic possibilities involving dotted and/or syncopated rhythms. Though many of these rhythms originated from ragtime, Copland points out that "ragtime is much inferior to jazz and musically uninteresting; it consists of old formulas familiar in the classics which were rediscovered one day and overworked" (Copland, 2004: 84).

The next step towards modern jazz began with the fox trot. The bass remained consistent--four straight quarter notes. The second and fourth beats were accented instead of the first and third in ragtime. The overlying rhythm also changed and was often written as straight eighth-notes, tied across the middle of the bar. Tying eighth- 
notes across the middle of the bar effectively eliminates the strength of the third beat of the measure. (Traditionally the first and third beats are strongest in a group of four). This obfuscation of the beat was a relatively new concept, especially in contemporaneous popular music (Copland, 2004: 87). It also caused a regrouping of the beats according to their strength or accent: three eighth notes, one quarter note (equivalent to the two tied eighth-notes), followed by three eighth-notes (1-2-3: 1-2: 12-3). Or, condensing the last two groups, we arrive at one group of three eighth-notes followed by a group of five eighth-notes (1-2-3: 1-2-3-4-5) (Copland, 2004: 84). This new rhythm also created syncopation that quickly spread in popularity. Fox trot rhythm may seem elementary, but this is the beginning of a fairly complex device called polyrhythm. Essentially, two independent rhythms occur simultaneously.

Subsequent developments retained the quadruple meter bass, but the melody was essentially triple meter (Copland, 2004: 85). Consequently, the inherent rhythmic stresses in the melody are contrary to the quadruple meter of the bass, creating two independent metrical organizations. George Gershwin's Fascinating Rhythm makes good use of this device, creating the feel of mixed meter without actually notating it as such. In this example, the left hand retains the unchanging four-quarter bass (actually steady eighth notes, but achieves the same effect) while the stresses and groupings of the melodic notes create the effect of changing meter (Copland, 2004: 86). It is little wonder that Copland calls it "rhythmically not only the most fascinating but the most original jazz song yet composed" (Copland, 2004: 86).

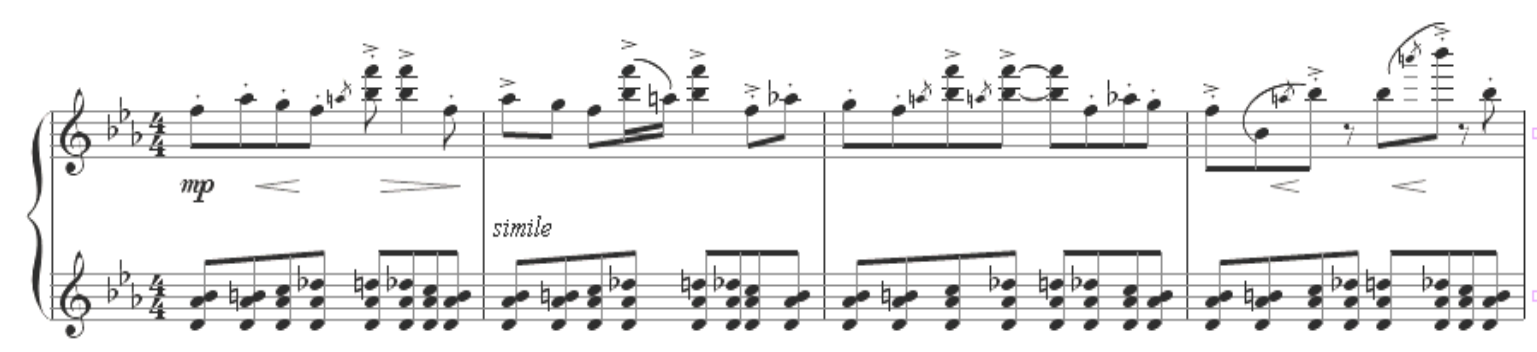

Figure 7: Gershwin, Fascinating Rhythm, mm. 3-6

According to Stanley Kleppinger in his article, "On the Influence of Jazz Rhythm in the Music of Aaron Copland," jazz rhythmic techniques from the 1920's can be summarized as "the organization of melodic patterns to produce metrical strata that move in and out of phase with an unchanging, periodic, simple-meter accompaniment" (Kleppinger, 
2003: 75). Copland's Concerto for Piano and Orchestra is an excellent example of this. In the 4/4 measures of the example below, Copland exhibits his use of the foxtrot rhythm; the left hand of the piano retains the "four quarter bass", while the right hand plays an eighth note, then quarter note, then quarter, eighth, and quarter. This is the definition of a polyrhythm as Copland explained in his article. The right hand's eighths and quarters can be grouped together for a group of three, essentially making this bar $3+2+3$. Copland's twist on the foxtrot polyrhythm can be seen in the second measure of the example below. Here, he changes the time signature to $3 / 4$ for both staffs, with two dotted-quarter notes for both hands. In so doing, he extends the pattern of the previous measure by adding two more groups of three. In the final two bars of this example, he consistently uses groups of three by tying chords across bar lines.

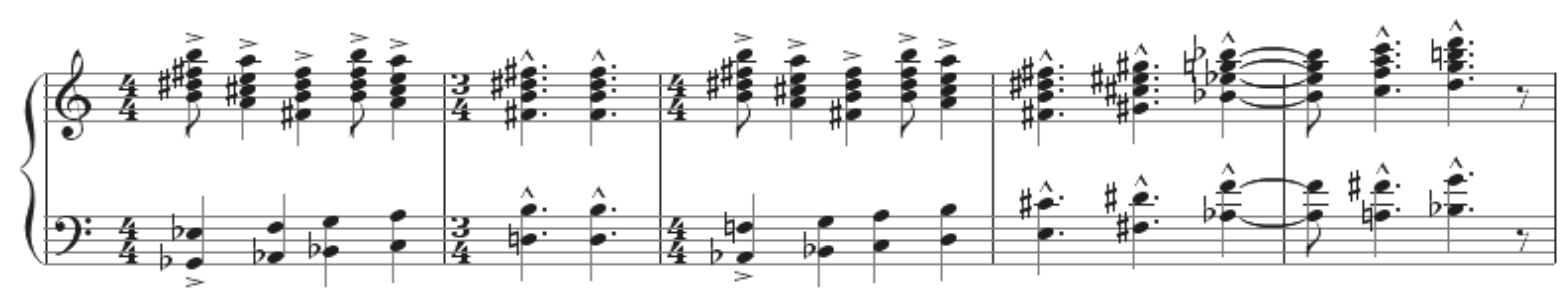

Figure 8: Copland, Concerto for Piano and Orchestra, Second Movement, mm. 39-43 (Copland, 1929).

Finally, Copland's article discusses the Charleston rhythm. This dispenses with the traditional four-quarter bass, emphasizing only the fox trot rhythm (1-2-3: 1-2-3-4-5) by joining both hands together in this rhythm. The syncopation of the fox trot remains yet it provides relief "from the old relentless 4/4 bass" (Copland, 2004: 86-87).

In addition to the fox trot rhythm, Copland also utilized the Charleston rhythm in his piano concerto (see below). In the following section of the piece, Copland uses the Charleston rhythm for eighteen straight bars in the piano part, building intervallically from a second (as seen below) to large tone clusters to whole octave chords. The Charleston rhythm was beneficial for Copland in this piece, as it allowed him to make use of the syncopation without having to retain the unrelenting four-quarter bass of the foxtrot. 


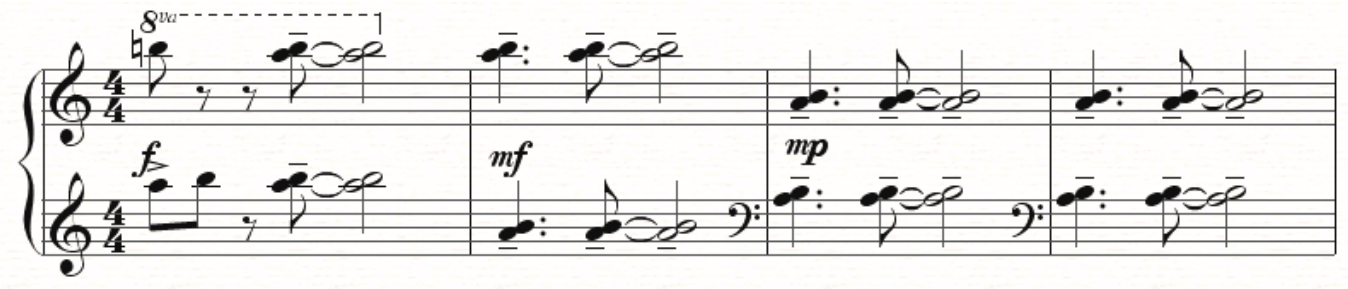

Figure 9: Copland, Concerto for Piano and Orchestra, Second Movement, mm. 168-171 (Copland, 1929)

Many years after Copland's article on “Jazz Structure and Influence” (1927), Bernstein authored an article entitled "the World of Jazz" (1955), in which he cites more derivations of jazz, such as Blues, Dixieland bands, Charleston bands, Swing bands, Boogie-Woogie, crazy Bop, cool Bop, and Mambo (Bernstein, 1954: 106). Some of these terms may seem outdated in the twenty-first century, thus showing how much jazz has evolved from the 1920's to the 1950's, when Bernstein's article was published, and continuing to the present.

Melody is the first element of jazz Bernstein's article addressed. Jazz uses a special variation on our traditional major scale, in which the third, fifth, and seventh scale degrees are lowered, creating "blue notes". These types of "blue note" scales are typically only used melodically, and the lowered scale degrees do not affect the way the harmony is structured (Bernstein, 1954: 110-112). This causes dissonance when the major key harmony and the blue note melody collide.

Bernstein makes use of blue notes in his piece, Prelude, Fugue \& Riffs. For example, the alto saxophone in the example below draws specific attention to the blue notes by including both the regular scale tones and the lowered "blue notes" in the same melodic motif--from G to G\# in the first measure and D\# to D-natural in the third measure.

Eb A. Sax. 1

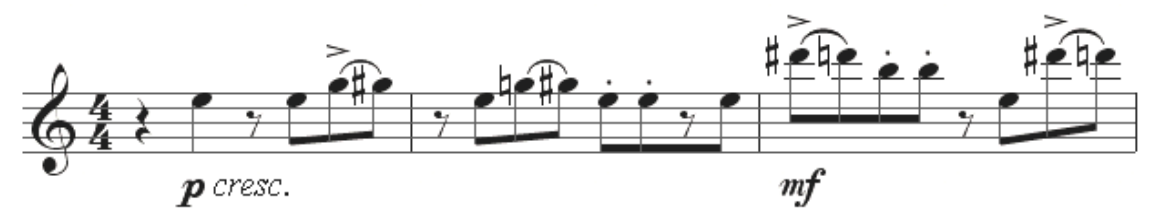

Figure 10: Bernstein, Prelude, Fugue \& Riffs, Second Movement, mm. 136-138

Next, like Copland, Bernstein discussed the innovation of jazz rhythms. However, Bernstein utilizes these concepts differently in his compositions. In the example below, Bernstein uses a technique similar to the foxtrot rhythm mentioned earlier. He retains 
the four-quarter bass, but the right hand notes are grouped differently and separated by rests, utilizing strong syncopations.

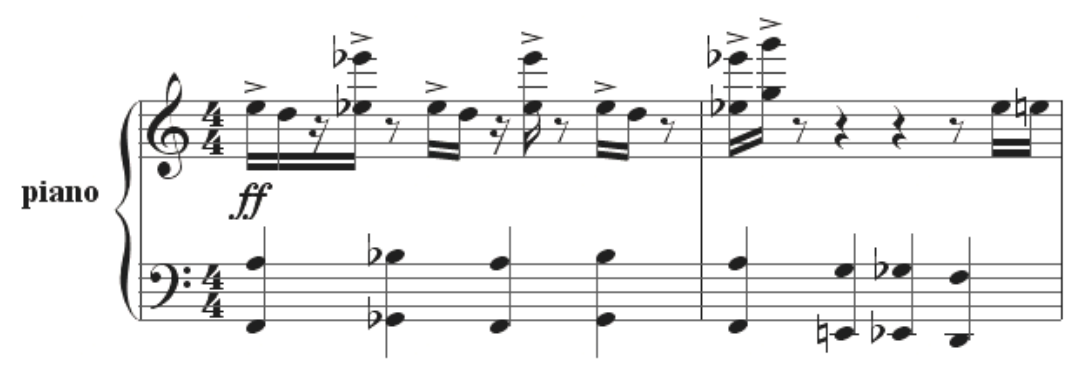

Figure 11: Bernstein, Prelude, Fugue \& Riffs, Third Movement, mm. 184-185

Displaying another one of Bernstein's derivations of the foxtrot rhythm, the next example disposes of the four-quarter bass, instead maintaining steady eighth notes throughout. The right hand of the piano is highly syncopated. In addition to the syncopation, Bernstein accents the fourth sixteenth note of each beat in the second bar, further reinforcing the weakest part of the beat, and setting the right hand rhythmically against the left. Another interesting point about the example below is that Bernstein presents the thematic material with the solo clarinet and the right hand of the piano follows in canonic fashion-a technique which one would expect of Baroque or Classical era art music, rather than a jazz-inspired piece from the twentieth century.

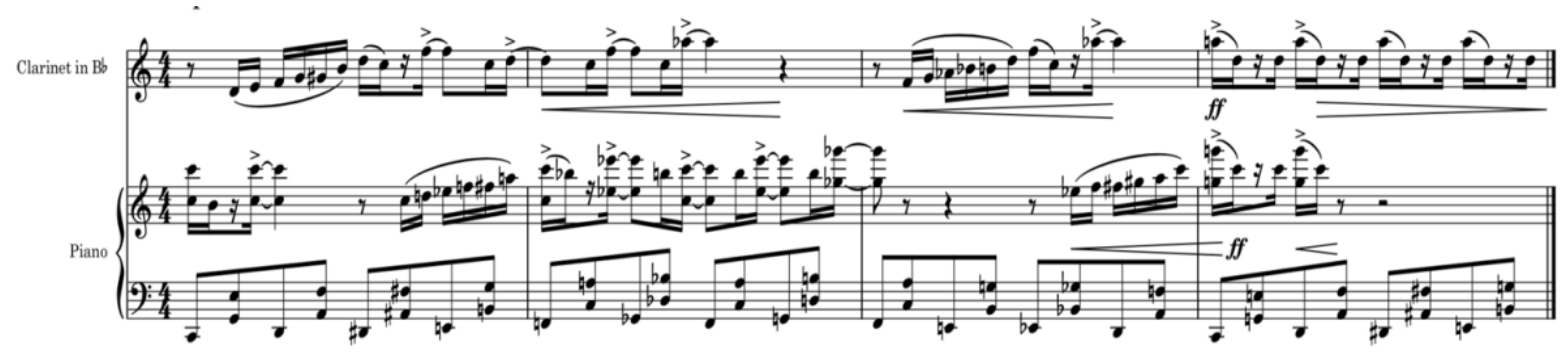

Figure 12: Bernstein, Prelude, Fugue \& Riffs, Third Movement, mm. 180-183

Next, Bernstein addressed the element of tone color in jazz. Mutes are often added to traditional instruments to change the timbre. Cup mutes and wah-wah mutes can be used for the trumpet, for example, and a plunger mute for the trombone. A wide variety of percussion instruments may be utilized, such as bongo drums, maracas, Cuban cowbell, vibraphone, and various cymbals, adding to the unusual and distinctive timbre of jazz music (Bernstein, 1954:118-120). These techniques can also be seen in Bernstein's Prelude, Fugue \& Riffs. The instrumentation includes tom-toms, hi-hat, snare 
drum, bass drum, xylophone, vibraphone, wood block, and timpani. Also, one of the first thematic statements of the piece is presented by the third, fourth, and fifth trumpets with Harmon mutes (see below).

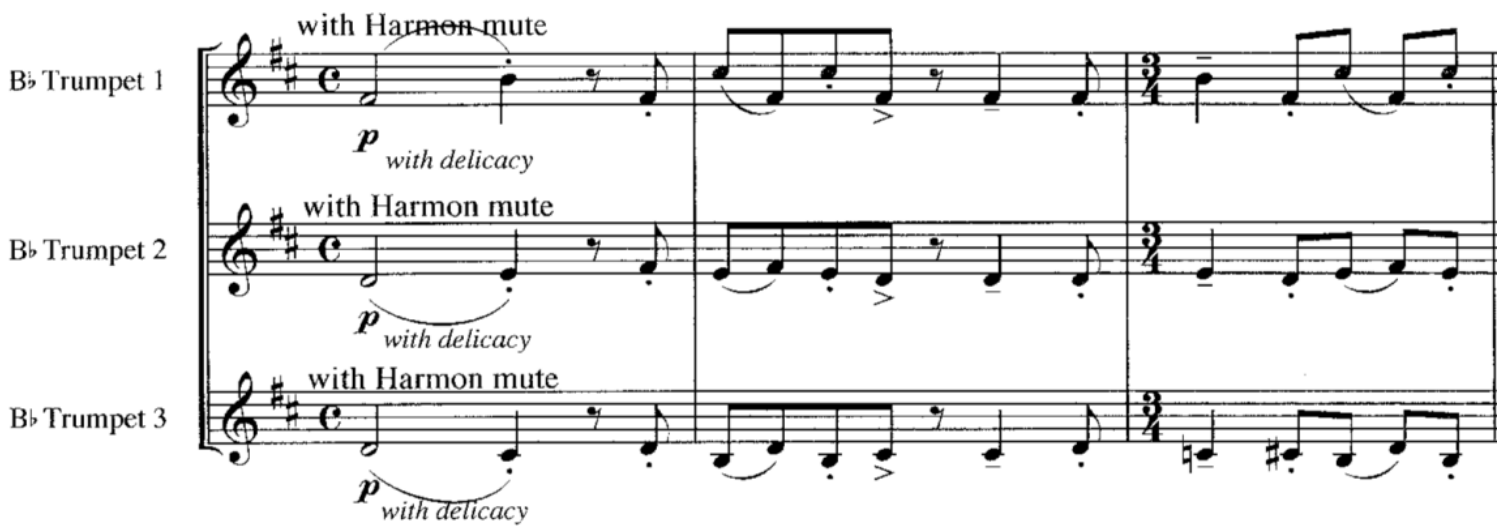

Figure 13: Bernstein, Prelude, Fugue \& Riffs, First Movement, mm. 5-7

Twentieth century composers, such as Debussy, Stravinsky, Ravel, Milhaud, Honegger, Martinu, Tansman, Satie, and Hindemith were all influenced by jazz (Copland, 2004: 87; Bernstein, 1962: 53). Debussy and Stravinsky were also influenced by ragtime rhythms and harmonies, which they incorporated into some of their compositions. Stravinsky's Ragtime for piano (1917-18) and Piano-Rag Music (1919) are two such examples. Ravel invokes the sounds of ragtime in his L'enfant et les sortilèges and employs jazz elements in his Piano Concerto in G. Arthur Honegger also incorporated jazz elements into Le roi David (1921) and Judith (1925-27). Bohuslav Martinu claimed jazz as a major influence in his twenties and thirties, utilizing jazz style in several of his pieces from that era: The Soldier and the Dancer, Les larmes du couteau, Les trios souhaits, La revue de cuisine, and his Sextet for wind and piano. Finally, the focus of his orchestral piece, Le jazz, was to imitate the big-band sound of Paul Whiteman's band. Darius Milhaud's La creation du monde, written one year before Gershwin's famous Rhapsody in Blue, not only evokes jazz influence, it is a unique blend of jazz and classical elements.

European composers considered jazz an exotic influence, and eventually, it lost its appeal. But to American composers, jazz was an indigenous music that infused their compositions and helped to develop a truly American sound (Copland, 2004: 87). Jazz has been "the most powerful, even if not the most permanent, influence upon American music" (Bernstein, 1982: 308). It "has entered the mind and spirit of America" and thus is assimilated into American compositions whether consciously or unconsciously. Some 
American composers influenced by jazz are Copland, Harris, Schuman, Sessions, Bernstein, and Piston. They "have written music that is American without trying, the result of an unconscious metamorphosis of jazz elements... This has been one of the strongest conditioning forces of the American musical language" (Bernstein, 1962a: 64). "Our composers are not attempting nationalistic music; they are merely taking advantage of their heritage quite naturally, and with no artificiality" (Bernstein, 1982: 98-99).

The evolution of jazz profoundly influenced the musical world of the twentieth century in all genres of music. The rhythmic techniques, blue-note melodies, extended harmonies, and timbres continue to infiltrate popular music, commercial music, rock ' $n$ ' roll, and art music all the way through to the present time. These 'new' sounds assisted American composers in establishing a new and Nationalistic identity, especially in the genre of American art music. An investigation of specific American nationalistic composers of the twentieth century follows, including a thorough look at what inspired and influenced them.

\section{George Gershwin (1898-1937)}

I don't think there's anyone in the country--or in the world, for that matter--who wouldn't know right away that Gershwin's music is American music. It's got 'America' written all over it (Bernstein, 1962b: 33).

Gershwin was not always accepted as a great composer, innovator, or influencer among 'serious' musicians. And while it is Bernstein's opinion that “Gershwin was certainly one of the true, authentic geniuses American music has produced," (Bernstein, 1982: 308) in the academic world of music, Gershwin is often looked down upon as merely a songwriter and not a serious composer of concert music (Bernstein, 1982: 307-308). His songs are immensely popular and "have become part of our language" (Bernstein, 1982: 308); his music has made its way into television commercials and movies, and is still frequently programmed in major concert venues throughout the world.

Gershwin's compositional career did not begin in the same way as a typical composer. He came from Tin Pan Alley, and his career was an endeavor to 'cross the tracks', so to speak, to serious concert music. In many ways he succeeded, but sadly did not live long enough to see his labor come to fruition (Bernstein, 1982: 308). It is impossible to 
predict what direction his career would have taken if he had lived longer, but one can imagine that he may have perfected the symphonic techniques with which he had been working in his later pieces.

According to Bernstein, "He has left music none of which is dull, much of which is mediocre, and some of which is imaginative, skillful, and beautiful" (Bernstein, 1982: 55). In the latter category, we find his many songs, his theater piece, Of Thee I Sing, concert pieces like Rhapsody in Blue and Concerto in F, and his opera, Porgy and Bess. Rhapsody in Blue, though one of his most popular pieces to this day, is considered by Bernstein to be structurally deficient. "It is episodic, loosely strung together by rather artificial transitions, modulatory devices, and secondhand cadenzas" (Bernstein, 1982: 308).

Perhaps Gershwin's greatest contribution to the musical world of the early 1900's was his incorporation of jazz elements into his concert music, or the "symphonization of jazz" (Bernstein, 1982: 55). This fusion was not something that came naturally for Gershwin. He was well acquainted with jazz rhythms and harmonies, but needed to learn the intricacies of symphonic writing (Bernstein, 1962a: 60). He found himself using typical European symphonic techniques as a structural basis in which to add jazz elements. His melodic gift was an enormous benefit to his musical language. Much of the aesthetic appeal of Rhapsody in Blue, for example, is the number of memorable or 'catchy' themes. In the same piece, his timbral combinations also show a departure from 'serious' concert music. From the first exaggerated glissando in the clarinet to his use of saxophones and muted brass, Gershwin effectively and creatively combines the colors of a jazz band with those of a traditional orchestra.

The excerpt below exhibits the roots of jazz rhythms discussed previously in this paper. In each of the measures below, Gershwin groups three sixteenth notes together by accenting the first of each group of three, which causes overlap between different beats of the measure, thereby creating syncopation. 


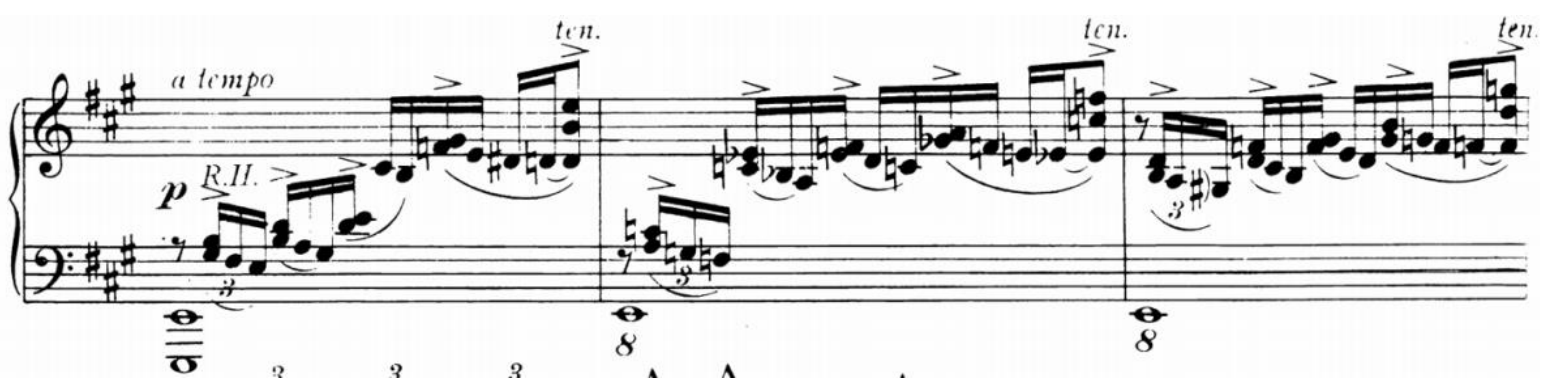

Figure 14: Gershwin, Rhapsody in Blue, mm. 30-32 (Gershwin, 1924)

The excerpt below illustrates Gershwin's influence of the blues. The linear, chromatic movement in the first two measures as well as the colorful extended harmonies, such as those highlighted below, contribute to the bluesy sound that Gershwin sought to infuse into his concert music.

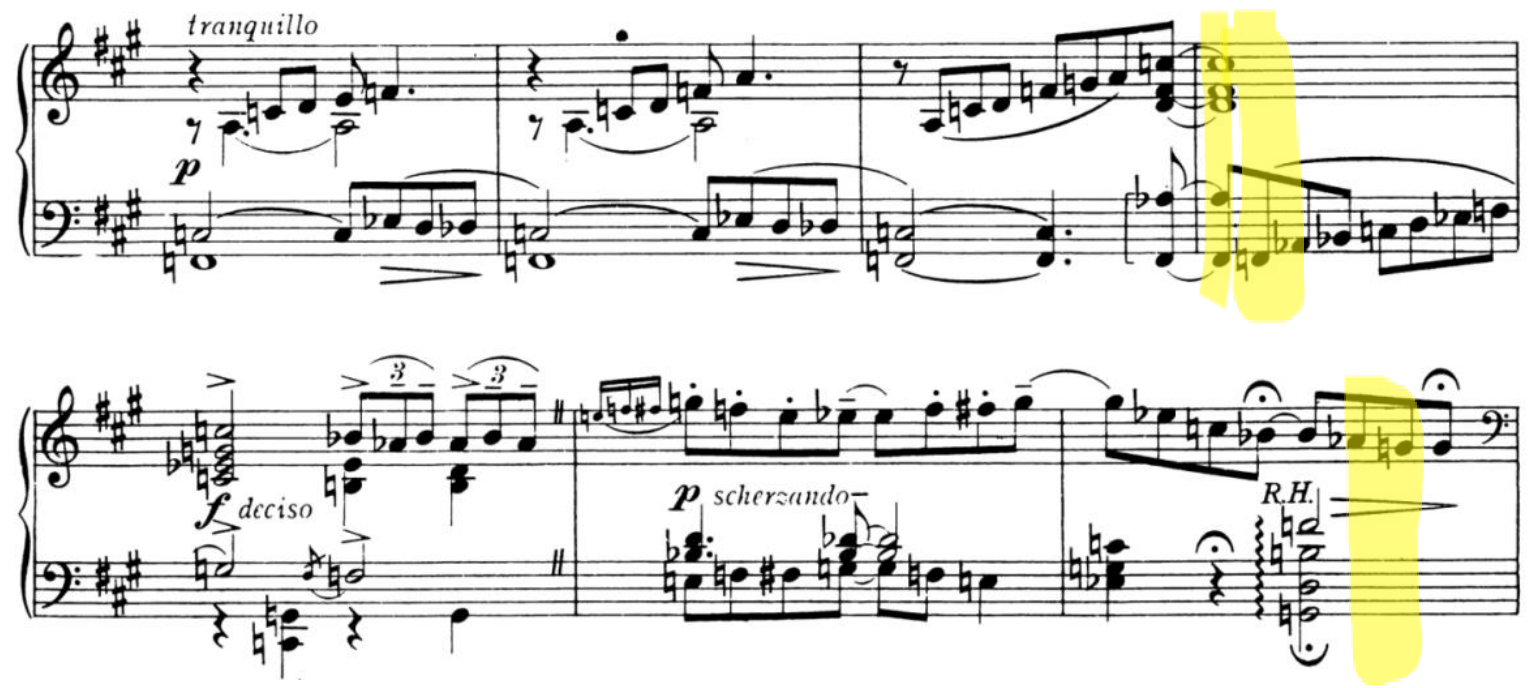

Figure 15: Gershwin, Rhapsody in Blue, mm. 48-54 (Gershwin, 1924).

"Certainly, the composer who used jazz most effectively was Gershwin" (Bernstein, 1962b: 41). He was ground-breaking in blending jazz elements with traditional symphonic techniques and was soon to be followed by other American composers. Gershwin's use of jazz made significant progress towards the development of a true American sound. There is no doubt that "Gershwin was, and remains, one of the greatest voices that have ever rung out in the history of American urban culture" (Bernstein, 1982: 309). 


\section{Aaron Copland (1900-1990)}

Copland's innovations contributed a great deal to the development of an American sound. From some of his earliest compositions, a uniquely modern voice could already be detected. For example, at the premier of his Symphony for Organ and Orchestra, the conductor, Walter Damrosch addressed the audience, saying, "If a young man at the age of twenty-three can write a symphony like that, in five years he will be ready to commit murder" (Walter Damrosch quoted in Copland, 1968: 157). Presumably these comments stem from an anti-modern sentiment, but Copland made a strong statement about his compositional style with this piece and was not swayed by such criticisms. On the contrary, Copland maintained a sense of humor and perspective regarding this piece, exhibited in the following letter to a friend, in which he said, "When the Concerto is played again, ('O horrid thought!') we must see if we can't get the police to raid the concert hall to give a little added interest to this 'horrible' experiment" (Copland, 1927).

Not discouraged by such negative reviews as those from Mr. Damrosch, Copland continued to experiment in his compositions of the next several years. Like Gershwin, he experimented with jazz elements in some of his pieces including Music for the Theater and Concerto for Piano and Orchestra. Feeling that he had done all he could with the idiom, the Concerto was his last conscious use of jazz techniques. "It was an easy way to be American in musical terms, but all-American music could not possibly be confined to two dominant jazz moods" (Copland, 1968: 159). Though the Concerto was his last conscious use of jazz techniques, his propensity for rhythmic complexity and vitality, which was originally inspired by jazz, persisted throughout his compositional career.

Copland's Piano Concerto is an excellent example of how jazz manifested itself in otherwise serious concert works. It is a "work of skill, structural merit, and great contrapuntal interest" (Bernstein, 1982: 58). As discussed earlier in this paper, in th is piece, as well as his other jazz-inspired works, Copland did not merely write a symphonic piece and then add jazz elements, but devised a way of reconciling the popular idiom with his own 'advanced style.' Like Gershwin, his aim was to symphonize jazz, but Copland achieved this in a much different way than Gershwin. Instead of simply using triadic harmonies, Copland uses polytonality (Bernstein, 1982: 58) to create a more sophisticated and complex harmonic structure, partially achieved through Copland's use of counterpoint. This is one of the ways in which Copland reconciles two 
diverse worlds: jazz melodies with blue notes, and his own modern idiom. Copland also introduces a virtual jazz band in the second movement of this concerto, like the "burlesque imitation of 1926 jazz bands" (Bernstein, 1982: 61), including soprano and alto saxophone, muted brass and copious percussion.

As a response to his perception of the widening gap between modern composers and audiences, in the mid 1930's Copland resolved to compose in the simplest possible terms, creating a more accessible style. His resulting works are some of his most wellknown and frequently performed today: El Salón México, Billy the Kid, and Rodeo.

In these early years of experimentation, Copland found himself drawn to Mexican and Latin-American sounds. His interest likely derived in part from his relationship with Mexican composer Carlos Chávez, as well as his visits to Mexico and South America. In a letter to a friend, Copland said, "Mexico offers something fresh and pure and wholesome--a quality which is deeply unconventionalized" (Crist, 2006: 101). And, in a letter to Carlos Chávez, he remarks that "it took [him] three years in France to get as close a feeling to the country as [he] was able to get in three months in Mexico" (Crist, 2006: 100-101). The resulting works from this connection to Mexico and South America include El Salón México, Danzón Cubano, and his Latin American Sketches. Their dancelike quality, irregular meters, asymmetrical phrases, and extreme rhythmic vitality contribute to the Latin-American blend for which Copland was striving during this time.

Danzón Cubano, for example, which Copland composed in response to a trip to Cuba in 1941, was first written for two pianos and then orchestrated by the composer at a later date. As can be seen in the piano excerpt below, Copland utilized syncopated, LatinAmerican rhythms and articulations in this piece. In many ways, he was emulating the traditional Cuban danzón, and though he understood that he was working from the outside, not as a native Cuban, he strove to use the popular materials and dances and translate them into his own voice (Dickstein, 2005: 97). 


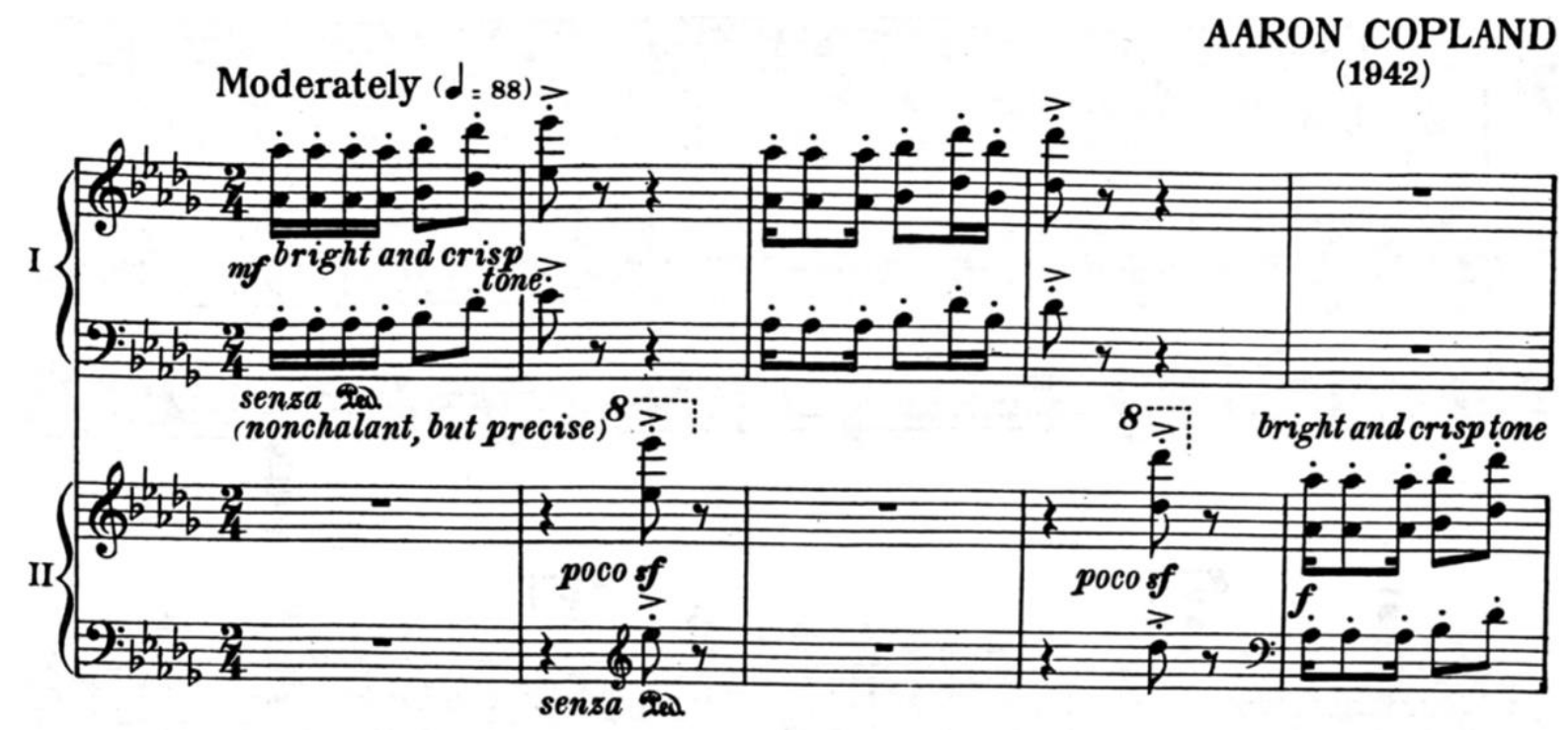

Figure 16: Copland, Danzón Cubano, mm. 1-5 (Copland, 1942)

The excerpt below is an excellent example of how Copland assimilated the Cuban danzón, while bringing his more modern sentiments to it. Throughout Copland's compositional career, a common thread of rhythmic experimentation is present. Quickly changing meters such as this can also be found in early works, such as his Passacaglia (1921), later works like El Salon Mexico (1938), and much later works, like his Duo for Flute and Piano (1971), just to name a few. In fact, this became one of his most distinctive characteristics.

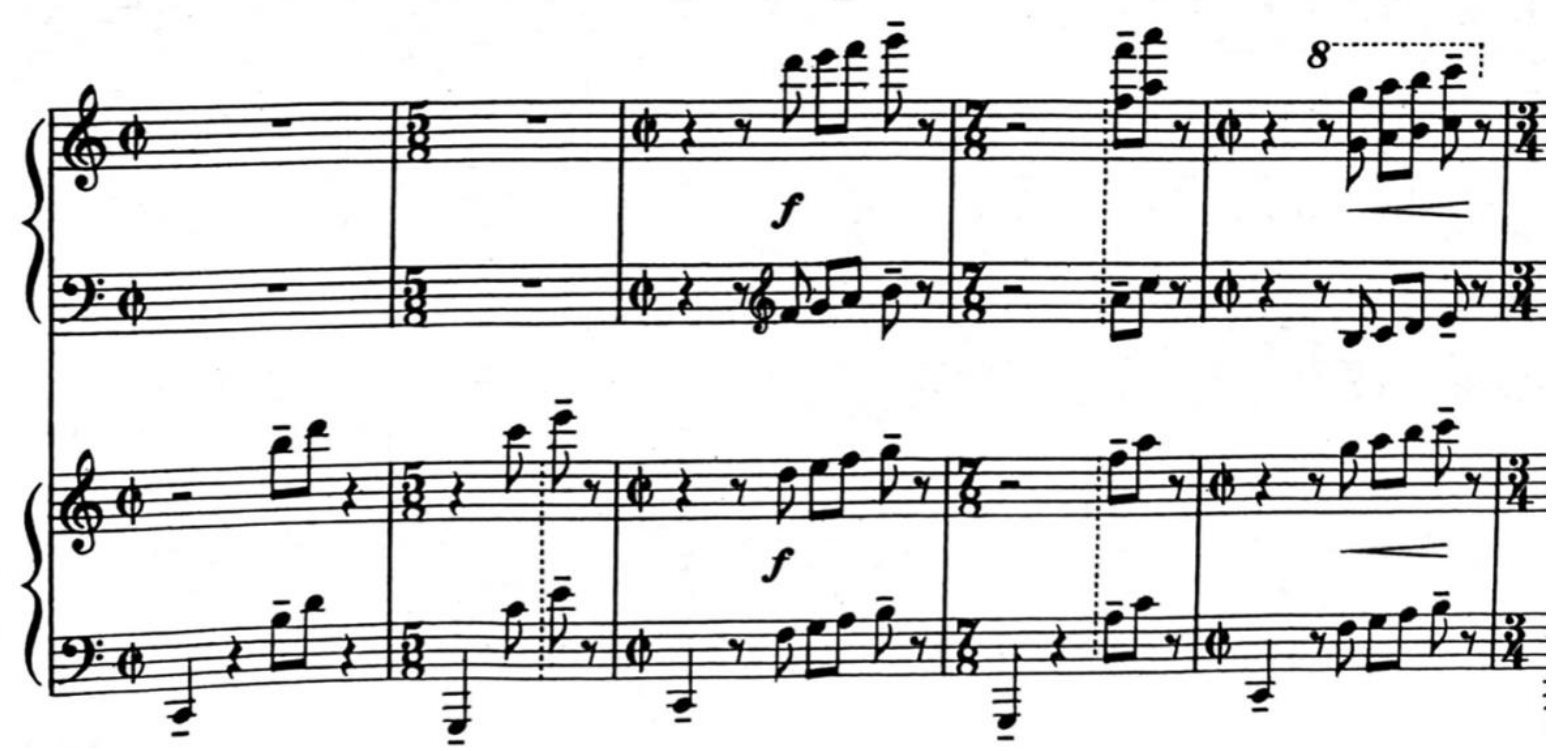

Figure 17: Copland, Danzón Cubano, mm. 149-153 
During Copland's trip to Havana, Cuba in 1941, which ultimately inspired the composition of this piece, he sat in a particularly large dance hall with two orchestras playing, one at each end of the hall (Pollack, 2000: 376). In the excerpt below, each piano part is layering a different theme, preexistent from an earlier part of the piece, on top of one another. This goes beyond strictly polyphonic texture, which one might expect from Palestrina, or one of his Renaissance contemporaries. In this excerpt, not only are both pianos playing different themes, they are both playing fortissimo in this section, which seems to suggest that the composer was not concerned with a delicate or diplomatic balance of ideas. Instead, this evokes the dual orchestras as he experienced them in Cuba, and also harkens back to Ives' use of layered themes and spatial experimentation.

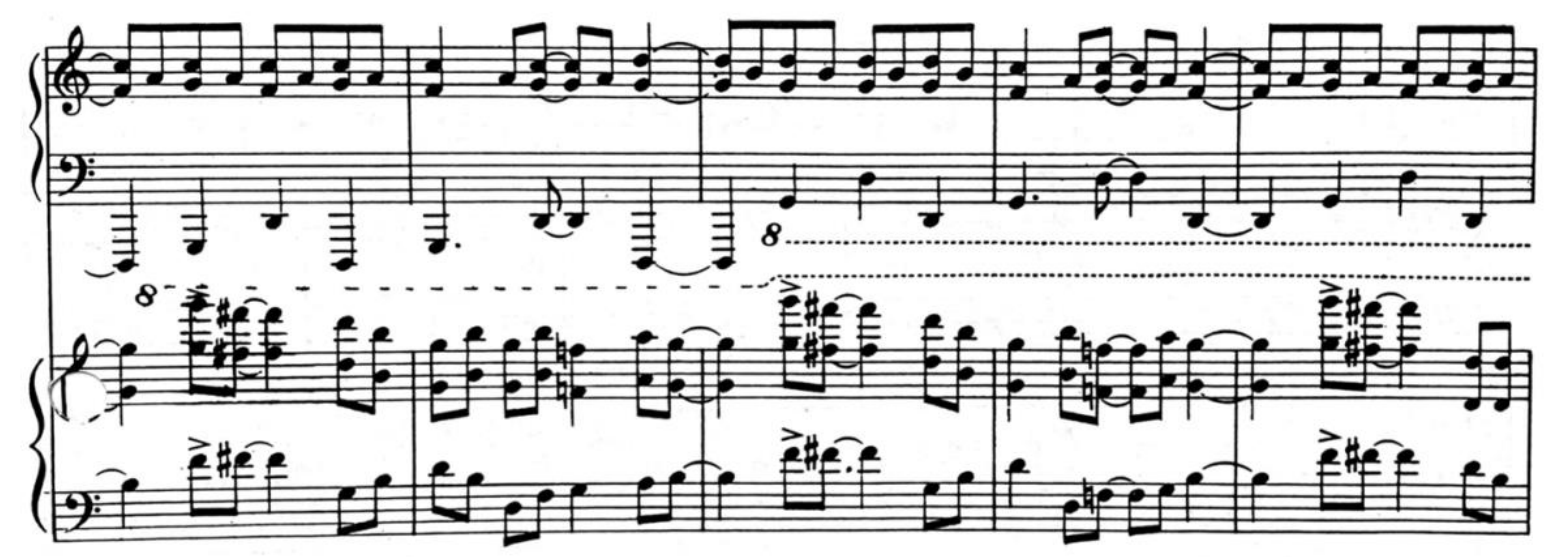

Figure 18: Copland, Danzón Cubano, mm. 249-253

Copland's affinity for Latin-American sounds was not all-pervasive throughout his compositional career, but, like jazz, the influence of these rhythms and harmonies helped define Copland's compositional voice and influence other composers in the process. His connections to this region were not only noted by composers and critics, but also by the government. In 1940, Nelson Rockefeller, the Coordinator of Cultural Relations with Latin America, appointed Copland to the Advisory Committee on Music (Crist, 2006: 133-134; Berger, 1945b: 425). The goal of this committee was to collect Mexican folk song material from native groups in remote areas of Mexico (Crist, 2006: 134-135). According to musicologist Carol Hess, "Surely if any US art-music composer is associated with musical Pan Americanism it is Copland. Not only did he serve the government in an official capacity, but he published on Latin American music and composed Latin-American-style works" (Hess, 2013: 192). 
In addition to jazz and Latin inspiration, Copland's 'American spirit' was portrayed in the ruggedness and open space in Billy the Kid through his characteristic use of spread out, open sonorities (Bernstein, 1962b: 48). This effect can also be seen in works such as Rodeo, Of Mice and Men, Lincoln Portrait, and Appalachian Spring.

In addition to Copland's compositions establishing a distinctly American sound, Copland lectured extensively in America and abroad on the importance of American music. For example, on a tour of South America in 1947, Copland gave a series of lectures in Brazil on American music, and provided commentary to his own compositions as they were played on the radio (Crist, 2006: 183). In 1955, on a tour of Europe, he also gave lectures on American music in Florence, Bologna, and Genoa (Copland, 1951a). Additionally, Copland conducted many American works in concerts around the world, including an all-Copland program at the Colon Theatre in Buenos Aires (Copland, 1947), an American chamber music concert in Rome, and a performance of "In the Beginning" for a Passover service in Tel Aviv (Copland, 1951b). Clearly, Copland made a priority of creating American music, making these developments known to others, and ultimately, making American music relevant to the world.

In their writings, both Copland and Bernstein discussed composers of contemporary and future generations that helped contribute to the development of an American sound. Among them are Virgil Thomson, William Schuman, Roy Harris, Roger Sessions, and Walter Piston.

\section{Virgil Thomson (1896-1989)}

According to Copland, "no country's musical life appears to be entirely mature until its composers succeed in creating an indigenous operatic theater" (Copland, 2004: 202). For this to be done, one must find a way of appropriately setting one's language to music. Virgil Thomson is one of the first American composers to appropriately address this problem and set America on its way towards having a national voice in this arena. His works are "thoroughly absorbing and attack the primary operatic problem of the natural setting of English to music" (Copland, 2004: 202).

Thomson was a completely original personality, and the diverse environments in which he lived - Kansas City, Missouri, where he was born; Harvard, where he resided for many years; and Paris, where he studied and remained for some time - contributed to 
this (Copland, 2004: 202-203). His first successful opera was Four Saints in Three Acts, with a libretto by Gertrude Stein (Copland, 2004: 203). Thomson produced a simple and natural setting of this complex text, giving "the words their true speech inflections just as if their literal meaning [was] continuously understandable, while at the same time creating a musical scene that was crystal clear in its emotional intention" (Copland, 2004: 204). To achieve success in this approach, Thomson created straightforward and unambiguous musical emotion.

Thomson's philosophy of simplicity resulted from his reaction against the overly pretentious modern music that dominated the country since the mid-1920's. He felt that composers were concerned with inventing new rhythmic and harmonic devices rather than the overall integrity of the music, which ultimately pushed him to the opposite extreme. Instead of complex and modern, Thomson began to compose in a more ordinary fashion, with a sweet, simple, sentimental, and even naïve quality (Bernstein, 1962b: 50). His point was simply that "modern music has forgotten its audience almost completely. [T] he purpose of music is not to impress and overwhelm the listener but to entertain and charm him" (Copland, 2004: 203).

Thomson's unique style developed with a combination of elements, such as hymn tunes, vocal exercises, Gregorian chants, Mozartean phrases, and French chansons, which when done with flair, contribute to the general flow of the music (Copland, 2004: 204).

According to Copland, Thomson's simplistic style is most effective in his vocal works, while his chamber works are less effective, never really freeing themselves from an air of "artful sophistication" (Copland, 2004: 203-204). One of his greatest attributes is his ability to set the English language to music in a unique and natural way. His compositions, including his Five Phrases from Song of Solomon through his Gertrude Stein Songs show his sensitivity to the innate rhythm of English. "It is as if Thomson merely wished to draw a musical frame around the words. This simplicity of the underlying musical urge is what permits the composer to put all stress on the exact setting of the rhythm of the language" (Copland, 2004: 203-204).

In addition to Four Saints, some of Thomson's best-known works include: The Mother of Us All, his second opera with a Stein libretto, and his film scores, Louisiana Story, The River, and The Plow That Broke the Plains. He also composed many choral and orchestral 
works, songs, solo piano pieces, and instrumental compositions. All of his works are unique and unpretentious. "He expresses only those feelings he really has; at the same time his attention does incline to move by means of joy and energy away from an inner emphasis to the outer world of nature, events, and people" (John Cage, quoted in Copland, 2004: 205).

\section{William Schuman (1910-1992)}

In Copland's estimation, "Schuman is generally ranked among the top men in American music" (Copland, 1960: 233). His mature works portray a sense of urgency, with ingenious instrumental techniques and experimental harmonies (Copland, 1960: 233). His String Quartet No. IV, for example, is somber, tentative, dark, and forbidding, unlike the eloquence and almost boyish optimism of his earlier works. Part of the dark character comes from his free use of tonality. It is less defined than previous works, even bordering on atonal. This piece is consistently dissonant in its chordal structure--more than any of his other works (Copland, 1960: 234). In his later works, Schuman employs a device where both major and minor intervals are sounding simultaneously, producing chords of a bitter-sweet nature. He alternates between chromatic and diatonic harmonies, which give the listener a sense of tension and relaxation respectively. "But it is the over-all experimental attitude that augurs well for the future" (Copland, 1960: 234). He produced a new method of expression, discarded the old formulas, and achieved a new and distinct style.

Schuman's rhythmic ingenuity and his expert treatment of instrumental timbre are part of his characteristic style. His rhythms -- skittish and personal, free and inventive (Copland, 1960: 234)--are difficult to perform because, though he stays within a regular metric format, the rhythmic impulse does not take bar lines into consideration. Some excellent examples of his rhythmic ingenuity can be seen in his String Quartet No. IV. The example below is indicative of his penchant for disregarding bar lines. In the time signature of $4 / 2$, Schuman uses a number of ties to obscure the sense of beat and bar lines. In the first measure, for example, instead of four clearly defined beats, the listener would only detect three accented 'beats'. The first beat, the second half of the second beat and the fourth beat are accented in this bar, and the fourth beat is tied over into the next bar. 


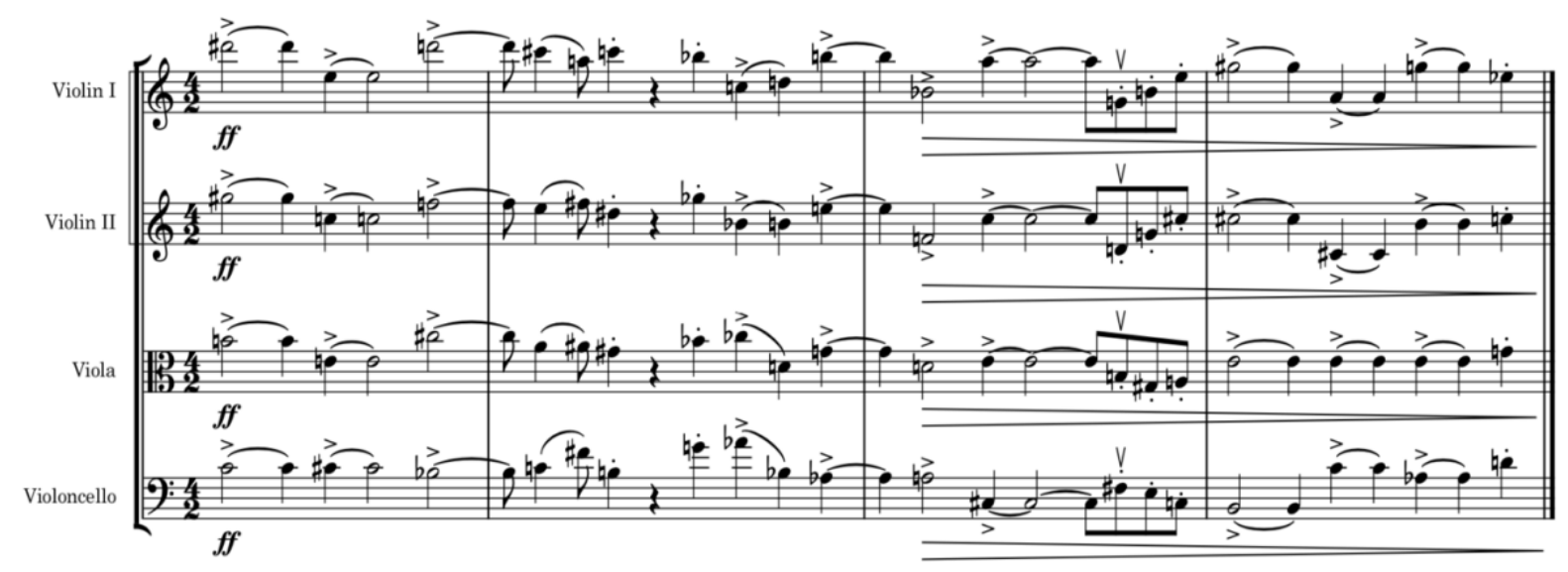

Figure 19: Schuman, String Quartet No. IV, Second Movement, mm. 52-55 (Schuman, 1951).

The next example shows numerous rhythmic ideas. First, his sense of rhythmic vitality is communicated with a dotted-eighth-sixteenth motive, followed by a measure of 'skittishness'. The second system of this excerpt exhibits a string of ties no doubt engineered to obfuscate the beat further.

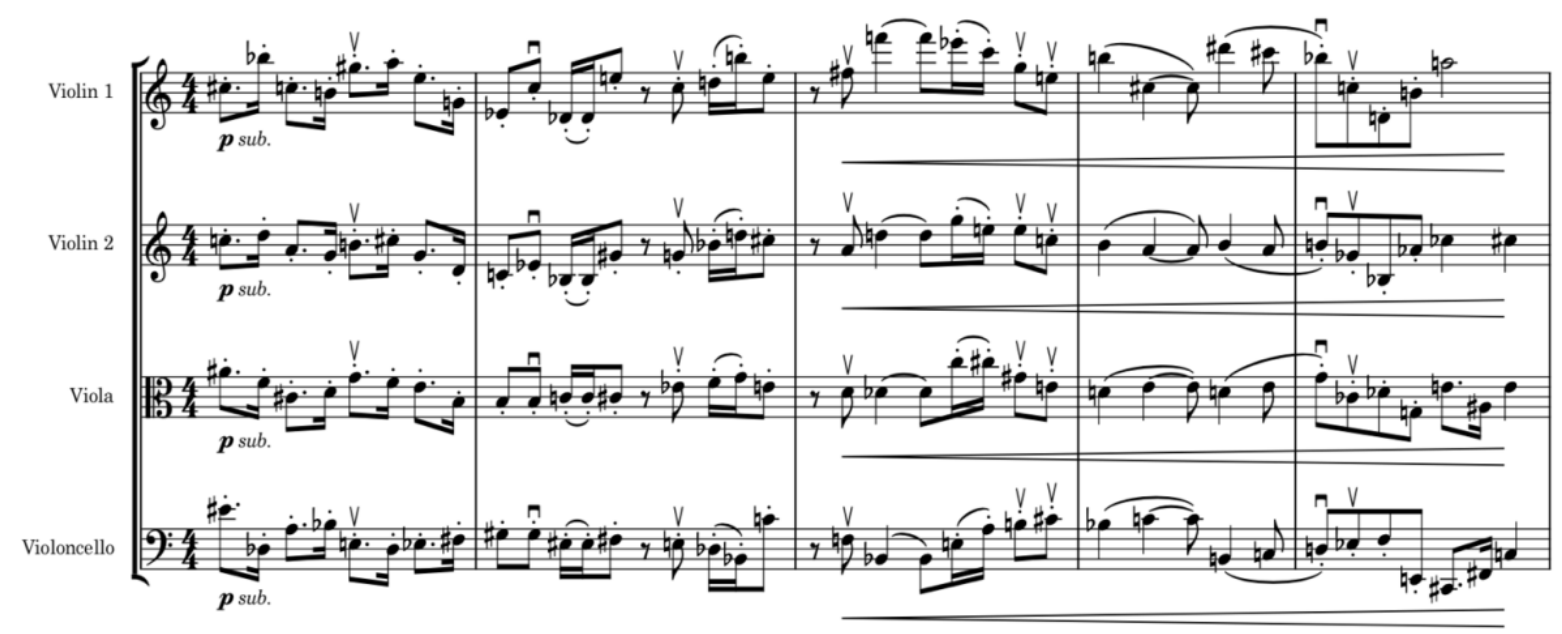




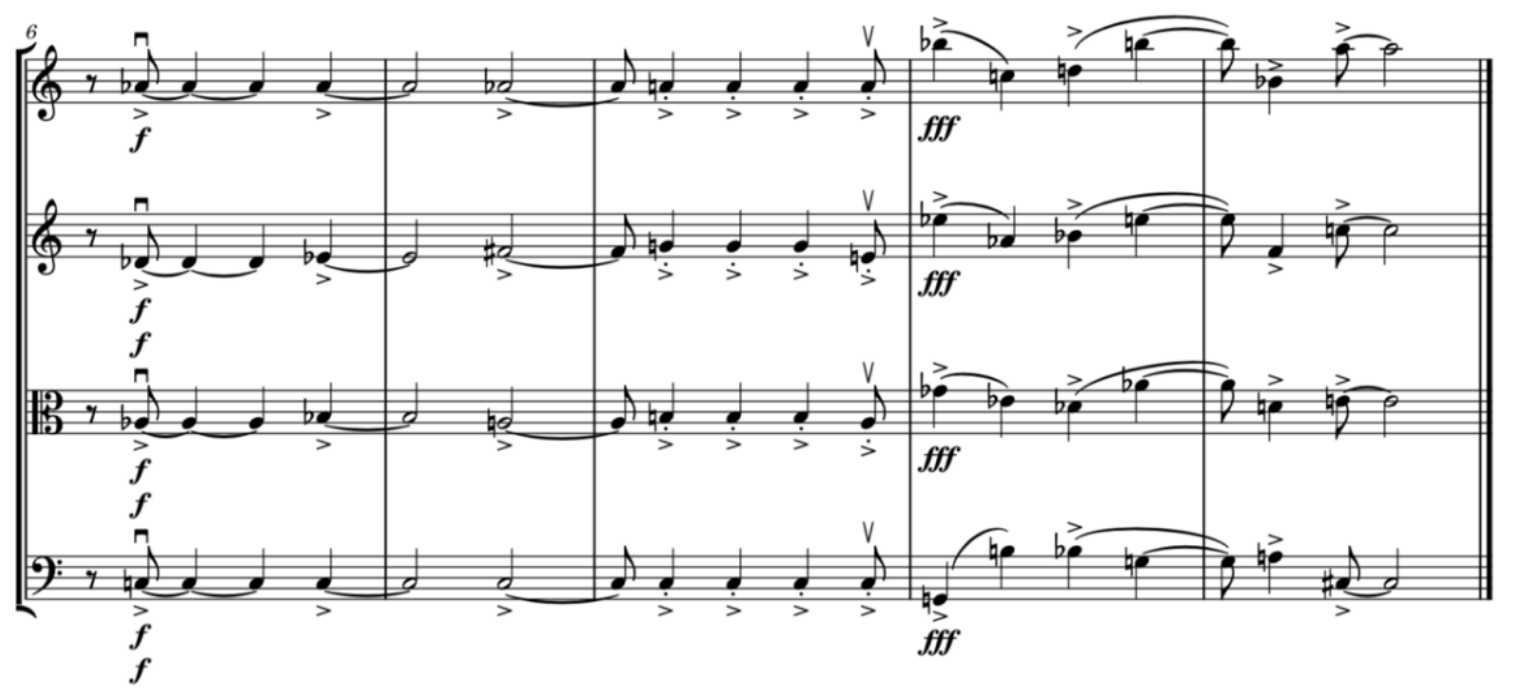

Figure 20: Schuman, String Quartet No. IV, Second Movement, mm. 190-199 (Schuman, 1951).

Schuman's American Festival Overture is another excellent example of his contribution to the development of an American sound. It portrays the American spirit-- loud, strong, and wildly optimistic (Bernstein, 1962b: 47). Schuman states that the piece is based on a street call that he used when he was a child to see if his friends wanted to come out and play (see example below). This is the type of vitality and youth of this concert overture.

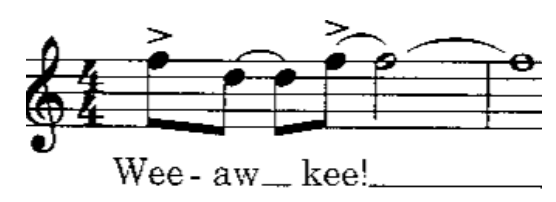

Figure 21: 'Childhood Street Call' (Bernstein, 1962b: 47).

The example below will show Schuman's adaptation of this childhood call in the opening of his overture.

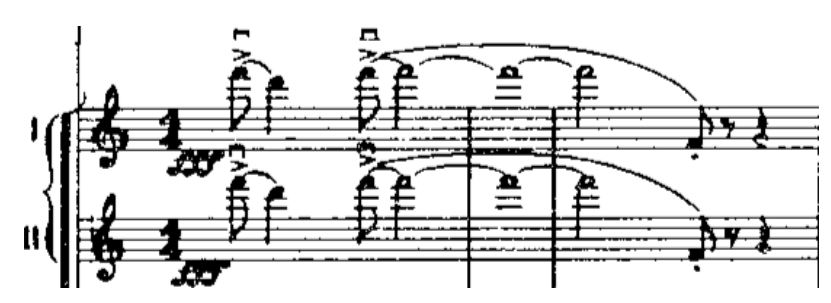

Figure 22: Schuman, American Festival Overture, First Movement, mm. 1-3 (Schuman, 1941).

There are multiple elements in the American Festival Overture that denote youth, strength, and optimism. His sense of rhythmic vitality is perhaps the most prominent, 
followed by his use of upward leaping intervals at the opening of new themes. The example below shows both youthful qualities of the composer. This following theme contains wide intervallic leaps near the beginning, followed by an accented, meandering melody. And although the composer uses chromaticism in this melody, the listener detects little in the way of dissonance, as the wandering and accented melody simply reinforces both Schuman's and Bernstein's assessment of children at play.

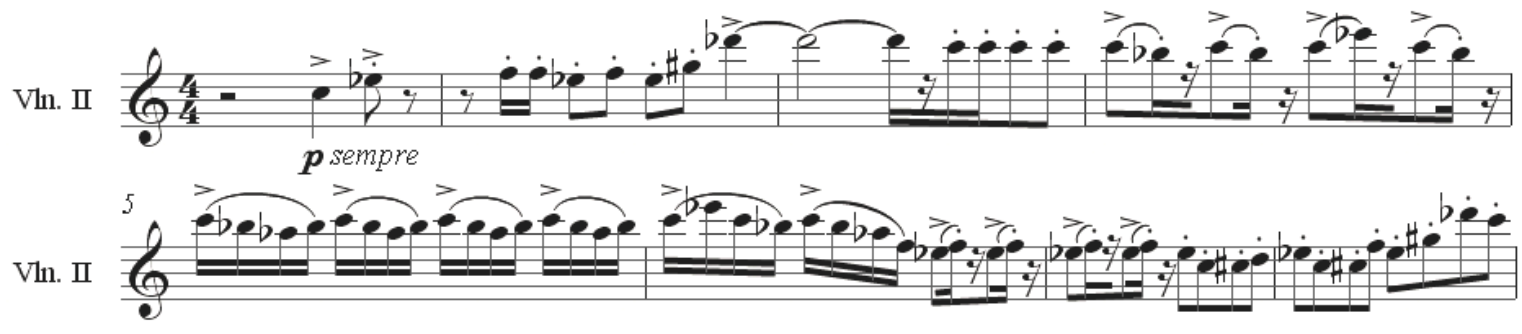

Figure 23: Schuman, American Festival Overture, mm. 92-98 (Schuman, 1941).

Perhaps not a national figure like Aaron Copland, William Schuman progressed towards the national sound for which American composers were searching during the early part of the century. The rhythmic vitality and youth portrayed in his music is an essential characteristic of American art music. Schuman did not claim jazz as a particular influence in his works. Instead, Copland states, the root of Schuman's rhythmic genius lies in non-Western influences, such as African and Asian influences (Copland, 1952: 84). The polyrhythms regularly used in these musical cultures were considered exotic, unique, and unusual to Western music. Schuman's incorporation of these rhythmic techniques in his otherwise American-sounding music not only gave a truly original sound to his works, but lent more credibility to the advancement of an American sound. Use of jazz techniques and simple quotation of folk materials were not all the movement had to offer, as we can see in the works of William Schuman.

\section{Roy Harris (1898-1979)}

According to Copland, "the work of Roy Harris is one of [the] principal manifestations... of the mainstream of American music today" (Copland, 1968: 118). In 1940, Harris' music was more frequently played, more praised, and more condemned than any other living American composer. The wealth of vitality "will keep his music alive for future audiences of Americans" (Copland, 1968: 118, 126). 
Unlike many composers who develop their compositional voice gradually, Harris' distinct personality existed from the very beginning (Copland, 2004: 174). It is one of the "most pronounced musical personalities" (Copland, 1968: 119) of anyone composing at the time. There were speculations that Harris' musical roots came from his pioneer, Oklahoma background, but Copland debunks this theory by reminding us that he moved to California at the age of five and lived in the suburbs of Los Angeles for the majority of his life (Copland, 1968: 119). Regardless, his music does sound distinctly American, with a strong sense of community, and a great breadth, full-bloodedness, power, spiritual purity and emotional depth. He writes music to address a large public, a sure sign of a composer from a large country (Copland, 1968: 120; Copland, 2004: 175, 177-178); describing, in his music, "America's physical, geographical vastness” (Mellers, 1948: 19).

His rhythms are characteristically American--a little jerky and nervous in some cases; crude and unabashed in others. In addition, his gift for melody is probably one of his strongest assets. He borrows Celtic folksongs, hymn tunes, and occasionally even Gregorian chant as a basis (Copland, 1968: 120; Bernstein, 1954: 223), and reworks or manipulates them into his own peculiar sound. His copious melodies and themes tend to be long, flowing lines, full of generosity and feeling, giving Harris a special character (Copland, 1968: 120). However, a byproduct of Harris' strong melodic gift is a lack of development. There are almost too many melodies being utilized in some cases. In his earlier works, he rejected established forms and structure, preferring to develop his own formal procedures. When these proved less than successful, he embraced older forms, viewing forms such as passacaglia and fugue as a challenge to incorporate into his compositions (Copland, 1968: 121).

Some of Harris' works show a lack of direction and perhaps an inadequate handling of larger forms. His setting of poetry for the voice is not his strongest quality, and music with programmatic tendencies does not always reflect the extra-musical content that it should (Copland, 1968: 122-123). Some of his greatest works, however--his Sonata for Piano and Concerto for Clarinet, Piano, and String Quartet--are full of zip and strong harmonic sense entirely personal to the composer. His Quintet for Piano and Strings and Third Symphony (Copland, 1968: 123-124) possess an original textural content, though Copland remarked that the latter "has some impossible string writing" (Copland, 1953). His music is built out of a "seemingly endless succession of spun-out melodies, which... 
together convey a remarkable impression of inexhaustible profusion of melodic invention" (Copland, 1968: 124).

Harris's rhythmic and melodic innovations can be seen in his Sonata for Piano. The following example from the first movement exhibits his rhythmic innovation. In this section, he changes time signatures from $9 / 4$ to $11 / 4,14 / 4$, and later, $16 / 4$, producing a sense of uncertainty. However, at a slow pace, spacing the bar lines so far apart, the listener loses any rhythmic pulse whatsoever. This loss of rhythmic pulse along with the melismatic nature of the eighth note passages in the following example show the influence of Gregorian chant previously cited by Copland.
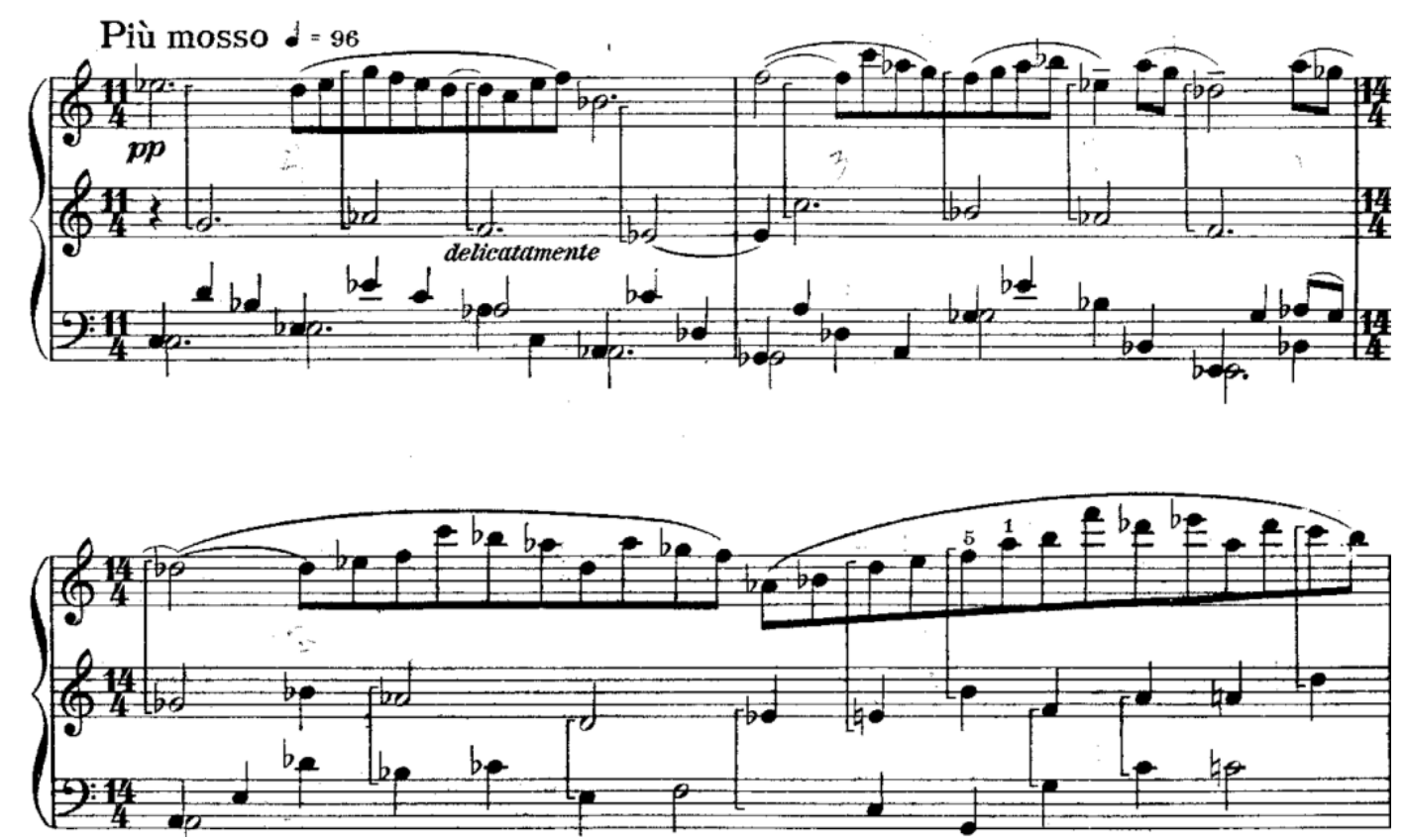

Figure 24: Harris, Sonata for Piano, Second Movement, mm. 26-28 (Harris, 1931).

Another example from Harris's Sonata for Piano, third movement Coda, employs almost exclusively parallel octaves and fifths, creating a hollow, medieval feeling. This could be attributed to an influence of Gregorian chant or of Debussy, as it is an excellent example of planing. 
CODA

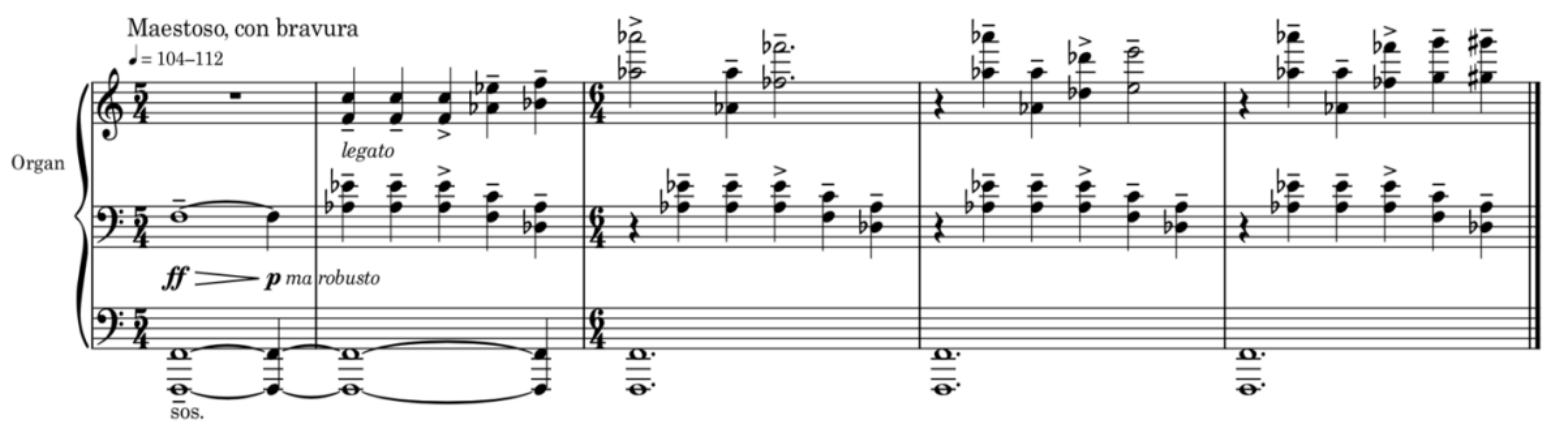

Figure 25: Harris, Sonata for Piano, Third Movement, mm. 102-106 (Harris, 1931).

Harris exhibits numerous rhythmic experiments in this piece, many of which can be seen in this next example. Here, he ties notes across bar lines (measure 23-24) and simply carries beams of eighth notes across bar lines in several measures. This is one example of the rhythmic vitality, mentioned by Copland.

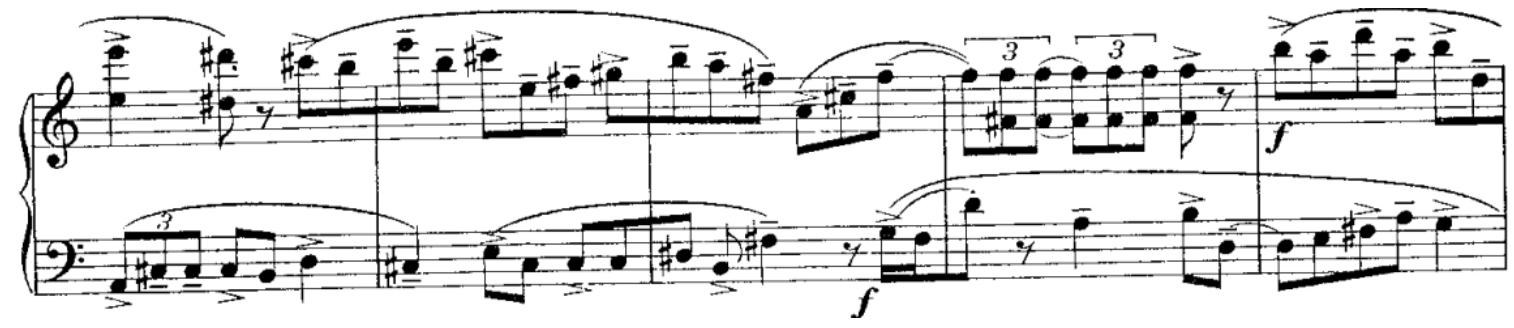

Figure 26: Harris, Sonata for Piano, Third Movement, mm. 21-25 (Harris, 1931).

These compositional techniques rank Harris among the top American art music composers of his generation. His rhythmic devices are varied and plentiful. For a composer to juxtapose an audible lack of rhythm in one section of a piece with a vigorous, almost chaotic, aggressive rhythmic section, as in the last example, is truly unique. The plethora of ideas in this sonata do suggest a lack of development, as Copland mentioned, but his strikingly original personality, his daring approach to music and the distinct fighting quality that can be found in many of his works portray the true American spirit.

\section{Carlos Chávez (1899-1978)}

Carlos Chávez lived and worked in New York for several years, and many of his works were performed in New York concerts of the International Composers' Guild. In this sense, according to the 'Dean of American Music,' Aaron Copland, "he belongs with the composers of the United States, for he owes much to our country" (Copland, 1968: 145). 
In the twentieth century, Chávez was considered a completely modern composer, with all the essential traits of modernism: "rejection of Germanic ideals, the objectification of sentiment, the use of folk material in its relation to nationalism, the intricate rhythms, [and] linear as opposed to vertical writing" (Copland, 1968: 145-146).

Chávez taught himself harmony and composition, rejecting more conventional teachers. He analyzed works of previous masters, having no musical tradition from which to draw in Mexico. He was ultimately successful in "forging a music that is not only his own but is recognizably Mexican" (Copland, 1968: 146).

His first Mexican ballet, The New Fire draws from Native Mexican folk songs for its themes. This was his first opportunity to turn away from the style and techniques of the European masters and embrace his own indigenous folk material. In this early ballet, he quoted folk songs literally, while a few years later he composed three sonatinas in which no folk melodies were specifically quoted. By this time, he had digested the material and created a characteristically personal sound, while still reflecting a Mexican influence. "As a whole the folk element has been replaced by a more subtle sense of national characteristics" (Copland, 1968: 147). His strong, deliberate, persistent, relentless, and uncompromising music is characterized by a stark, clear, and earthy style, with no frills, nor anything extraneous. It is almost as if he is expressive in his inexpressiveness (Copland, 1952: 91).

Two of Chávez's best-known orchestral works, Sinfonía India and Sinfonía de Antígona, show different approaches to nationalism (Copland, 1968: 148; Bernstein, 1962b: 174). While they are both distinctly Mexican, the former can be described as a "medley of delightful native tunes," and the latter uses no Mexican folk material at all (Copland, 1968: 148). The former also utilizes several Native Mexican percussion instruments that "give the work a special color" (Copland, 1936). Other contrasting works include: $H P$, which Copland described as a "youthful and colorful score once it is 'discovered"' (Copland, 1959), Blues and Fox, the Huapango section of HP, and the Aztec images in Xochipilli-Macuilxóchitl-- all have Chávez's personality, clarity, and sharpness of outline (Copland, 1959). His Piano Sonata and Sonata for Four Horns are both extremely personal, obstinate in purpose, and also distinctly Mexican--Native Mexican, more specifically- with a stoic, stark, and somber character (Copland, 1968: 148-149). 
Chavez's Sinfonia No. 3 succinctly encapsulates his compositional career. It represents a more mature compositional style, having solidified his personal character in earlier years. In this sinfonia, he does not quote specific folk songs, but his melodies exhibit folk elements and rhythms that portray a Mexican folk feel. The example below is an oboe melody presented in the first movement, Introduzione. This melody displays some chromaticism as well as lowered scale degrees that were previously sharp (the Gnatural in measure 6, for example).

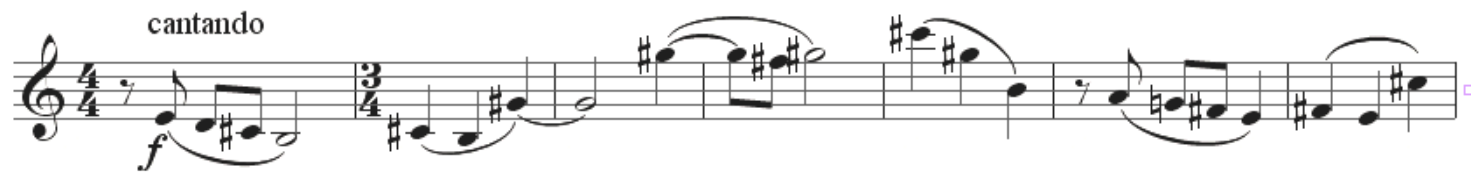

Figure 27: Chavez, Sinfonia, First Movement, mm. 15-21 (Chavez, 1955)

The second movement of the Sinfonia shows Chavez's use of ostinato rhythms in $12 / 8$, providing a lilting or galloping accompaniment to the melody. This type of compound meter and simulation of galloping is also common of Mexican folk music and one which Copland also made use of, most notably, in his El Salon Mexico.

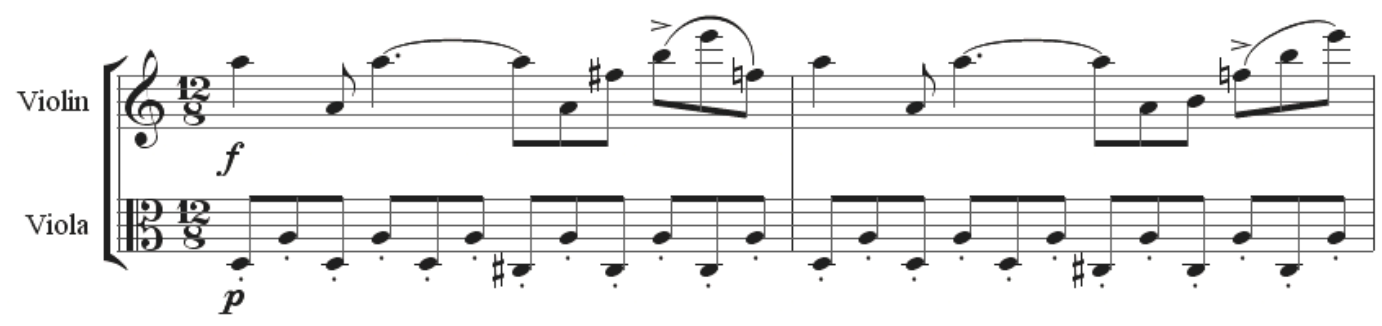

Figure 28: Chavez, Sinfonia, Second Movement, mm. 1-2 (Chavez, 1955)

Leonard Bernstein, in one of his Young People's Concerts, described music that used a 'childhood call.' Specifically, he identified the American Festival Overture of William Schuman as an example. Chavez uses a similar childhood call in the first movement of Sinfonia--one which Bernstein also discusses in one of his lectures at Harvard. This childhood call (see example below) is made up of three fundamental tones Bernstein calls Musical Phonology, the idea that a "worldwide, inborn musical grammar" exists based on "the similar idea of a universal grammar underlying human speech" (Bernstein, 1976: 7). 


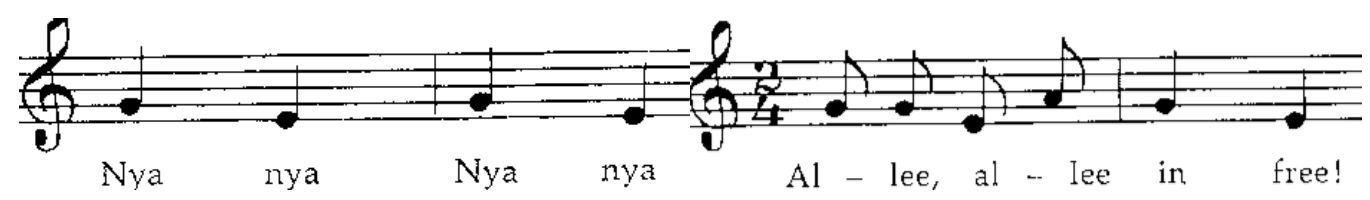

Figure 29: 'Childhood Call' (Bernstein, 1976: 7)

Chavez uses these fundamental tones in one of the first movement themes, which recurs in later movements of the Sinfonia (see example below).

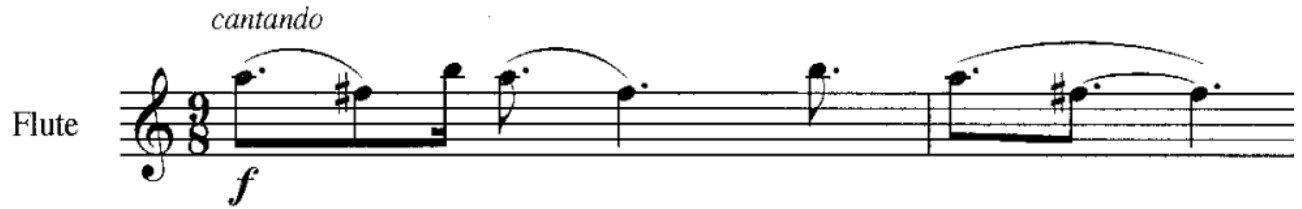

Figure 30: Chavez, Sinfonia, Fourth Movement, mm. 70-71 (Chavez, 1955)

This piece also shows Chavez's flexibility as a composer blending folk elements, modern techniques, and classical forms. For example, Chavez composed a full-fledged fugue in the third movement. The subject is first presented by the flute, and then the bassoon, followed by clarinet, and finally, contrabassoon. The first subject and beginning of the bassoon statement is shown below.

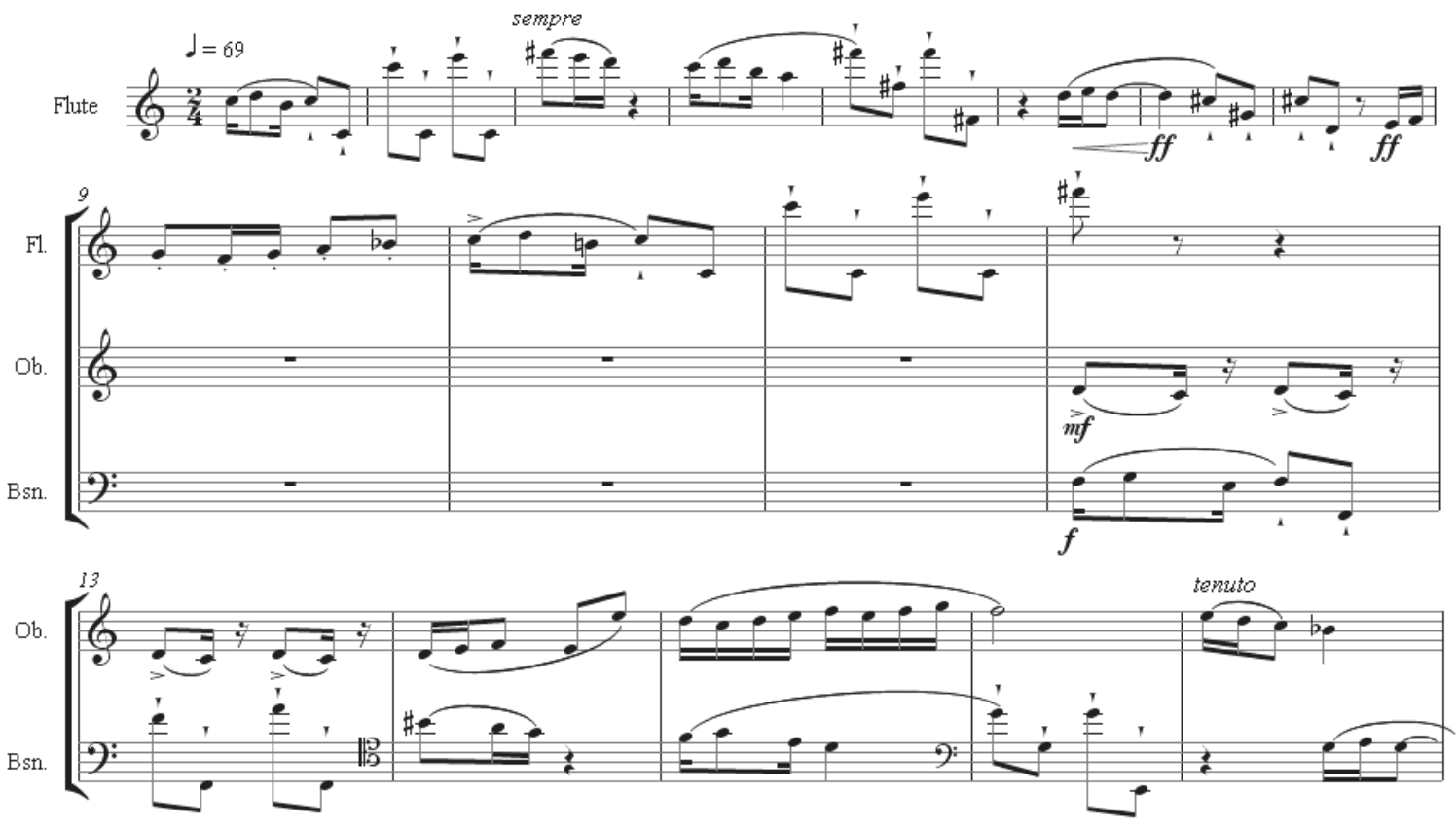

Figure 31: Chavez, Sinfonia, Third Movement, mm. 1-17 (Chavez, 1955) 
Chavez's twist on the use of a traditional fugue form can be seen in the next example. Here, the viola and cello are playing the fugue subject in unison and in counterpoint with the timpani. An emphasis on percussion is common in modern music, but it is a truly unique juxtaposition of elements for Chavez to utilize the timpani for real melodic and thematic content rather than simply rhythmic punctuation.

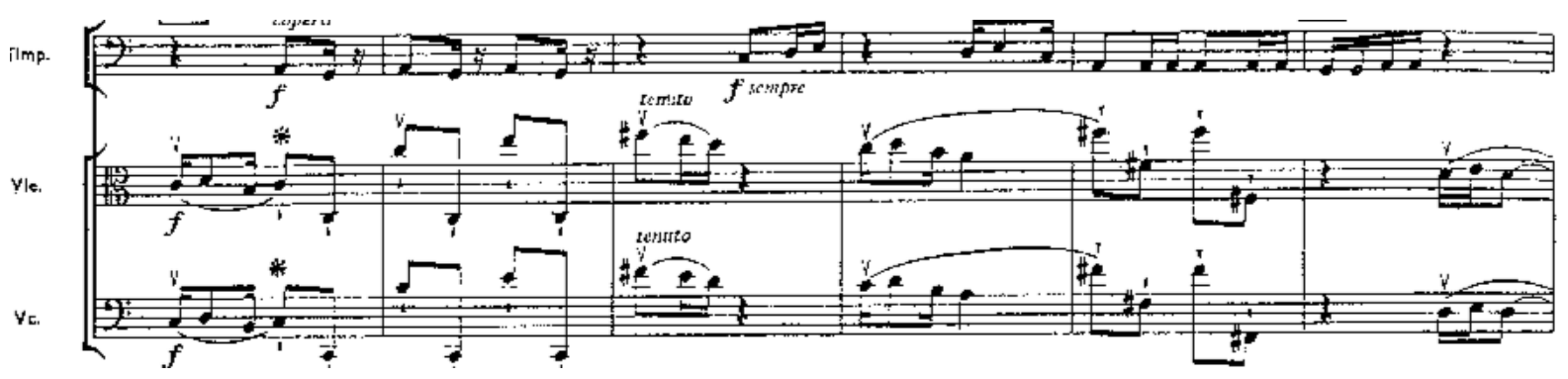

Figure 32: Chavez, Sinfonia, Third Movement, mm. 171-176 (Chavez, 1955)

Chávez is a first-rate Mexican composer and one of the first from the Americas to break away from a strict European tradition. Composers of the United States cannot borrow as readily from Chávez's treasury of folklore, given that they cannot easily relate to the folk material of Mexico, but his compositions have "stimulated and instructed" (Copland, 1968: 150) both contemporary and future composers. "Here we have one of the first authentic signs of a New World with its own music" (Copland, 1968: 150).

Aaron Copland and Carlos Chávez enjoyed a friendship and cross-pollination of compositional influences throughout their careers. Copland visited Chávez in Mexico on numerous occasions and became acquainted with the folklore that had influenced Chávez. These influences can be seen in some of Copland's works, such as El Salon Mexico and Danzón Cubano. Chávez also maintained a reputation of national and international importance. He was sought after as a prestigious guest teacher at Tanglewood, following in the footsteps of composers like Hindemith, Milhaud, Honegger, Martinu, Messiaen, Ibert, and Dallapiccola (Copland, 1952). From the multiple visits and letters exchanged between the two composers, it is clear that Copland thought very highly of Chávez. One of the strongest examples can be found in a letter from Copland to Chávez in 1948, where Copland describes an occasion where he reportedly "upset VillaLobos considerably at a meeting of the Academia Brasileira de Musica by talking at too great a length about the achievements of one Carlos Chávez!" (Copland, 1948). Copland's 
esteem for the composer can further be seen in the following statement made after Chávez's death:

Carlos Chavez and I had been friends and composer-colleagues for half a century. His role during that period as composer and conductor and his country's chief animator of musical life is now a part of music history.

It is impossible to imagine the Mexican musical scene of the past fifty years without his leadership. He and I felt ourselves brothers-in-arms, desirous of having the musicoartistic life of our two countries join the twentieth century.

His contribution as conductor, teacher and leader of the musico-cultural life of Mexico for half a century will always be remembered. But most of all, Carlos Chavez would wish to be remembered, and rightfully so, as composer. As I once wrote: "Whatever his musical style, harsh or mellifluous, it is the music of a personality, one of the most striking of our time" (Copland, 1978: 1).

\section{Conclusion}

Developing a truly American sound was a difficult task for the art music composers of the twentieth century. Even before the turn of the century, American composers were urged by Dvorák to produce American compositions simply by quoting indigenous folk music. It became evident that this approach would not ultimately be successful for two reasons. First, these American composers had no connection with the folk material they were using, and second, the resulting pieces were more like patchwork quilts than cohesive pieces of music. The composers' styles and compositional techniques were not unified with the blindly quoted folk songs. With the evolution of jazz, however, American composers had a uniquely American music from which to draw. In this vein, we saw Gershwin's music and some of Copland's early works emulating jazz, adapting, and reconciling these very different genres of music. Copland also made use of folk material from the United States and Mexico, and many other composers followed his lead. From all of these influences, an American sound was developing; a sound that came from the individual and personal voice of the composer and reflected the true spirit of the country. "There are as many sides to American music as there are to the American people--our great, varied, and many-sided democracy. And perhaps that's the main quality of all: the many-sidedness" (Bernstein, 1962b: 50). 


\section{REFERENCES}

Berger, Arthur V. (1945a). “Aspects of Aaron Copland's Music” Tempo. 1(10): 2-5.

Berger, Arthur V. (1945b). "The Music of Aaron Copland” The Musical Quarterly. 31(4): 420-447.

Bernstein, Leonard. (1950). Prelude, Fugue and Riffs: for Solo Clarinet and Jazz Ensemble. London: Boosey \& Hawkes.

Bernstein, Leonard. (1954). The Joy of Music. New York: Anchor Books / Doubleday.

Bernstein, Leonard. (1962a). The Infinite Variety of Music. New York: Simon and Schuster Bernstein, Leonard. (1962b). Young People's Concerts. New York: Doubleday.

Bernstein, Leonard. (1976). The Unanswered Question: Six Talks at Harvard. Cambridge: Harvard University Press.

Bernstein, Leonard. (1982). Findings. New York: Anchor Books / Doubleday.

Chavez, Carlos. (1955). Sinfonia No. 3. London: Boosey \& Hawkes.

Cone, Edward T; Copland, Aaron. (1968). "Conversation with Aaron Copland" Perspectives of New Music. 6(2): 57-72.

Copland, Aaron. (1927). Letter from Aaron Copland to Nicolas Slonimsky. Manuscript/Mixed Material. Retrieved from https://www.loc.gov/item/copland.corr0086/.

Copland, Aaron. (1929). Concerto for Piano and Orchestra. New York: Cos Cob Press, Inc. Copland, Aaron. (1936). Letter from Aaron Copland to Serge Koussevitzky, February 3. Manuscript/Mixed Material. Retrieved from https://www.loc.gov/item/copland.corr0202/.

Copland, Aaron. (1939). What to Listen for in Music. New York: Penguin Books.

Copland, Aaron. (1942). Danzón Cubano. London: Boosey \& Hawkes, Inc. 
Copland, Aaron. (1947). Letter from Aaron Copland to Irving and Verna Fine.

Manuscript/Mixed Material. Retrieved from

https://www.loc.gov/item/copland.corr0595/.

Copland, Aaron. (1948). Letter from Aaron Copland to Carlos Chávez. Manuscript/Mixed Material. Retrieved from https://www.loc.gov/item/copland.corr0384/.

Copland, Aaron. (1951a). Letter from Aaron Copland to Irving and Verna Fine.

Manuscript/Mixed Material. Retrieved from

https://www.loc.gov/item/copland.corr0625/.

Copland, Aaron. (1951b). Letter from Aaron Copland to Irving Fine, April 3.

Manuscript/Mixed Material. Retrieved from

https://www.loc.gov/item/copland.corr0624/.

Copland, Aaron. (1952). Music and Imagination: The Charles Eliot Norton Lectures, 195152. Cambridge: Harvard University Press.

Copland, Aaron. (1953). Letter from Aaron Copland to Carlos Chávez. Manuscript/Mixed Material. Retrieved from https://www.loc.gov/item/copland.corr0414/.

Copland, Aaron. (1959). Letter from Aaron Copland to Carlos Chávez, May 6.

Manuscript/Mixed Material. Retrieved from

https://www.loc.gov/item/copland.corr0442/.

Copland, Aaron. (1960). Copland on Music. New York: Doubleday \& Company, Inc.

Copland, Aaron. (1968). The New Music: 1900-1960. New York: W. W. Norton \& Company, Inc.

Copland, Aaron. (1978). Letter from Aaron Copland. Manuscript/Mixed Material. Retrieved from https://www.loc.gov/item/copland.corr0571/.

Copland, Aaron. (2004). A Reader: Selected Writings, 1923-1972. New York: Routledge.

Crist, Elizabeth B.; Shirley, Wayne. (2006). The Selected Correspondence of Aaron Copland. Yale University Press. 
Dickstein, Morris. (2005). "Copland and American Populism in the 1930s" Aaron Copland and His World, 81-100. Princeton: Princeton University Press.

Gershwin, George. (1924). Rhapsody in Blue. Milan: G. Ricordi \& Co.

Harris, Roy. (1931). Sonata for Piano. New York: Cos Cob Press, Inc.

Hess, Carol A. (2013). "Copland in Argentina: Pan Americanist Politics, Folklore, and the crisis in Modern Music" Journal of the American Musicological Society. 66(1): 191-250.

Kleppinger, Stanley V. (2003). “On the Influence of Jazz Rhythm in the Music of Aaron Copland" American Music. 21(1): 74-111.

Mellers, Wilfred. (1948). "Aaron Copland and the American Idiom" Tempo. New Series (9): 17-20.

Pollack, Howard. (2000). Aaron Copland: The Life and Work of an Uncommon Man. Chicago: University of Illinois Press.

Schuman, William. (1941). American Festival Overture: for Orchestra. New York: G. Schirmer, Inc.

Schuman, William. (1951). String Quartet No. IV. New York: G. Schirmer, Inc. 